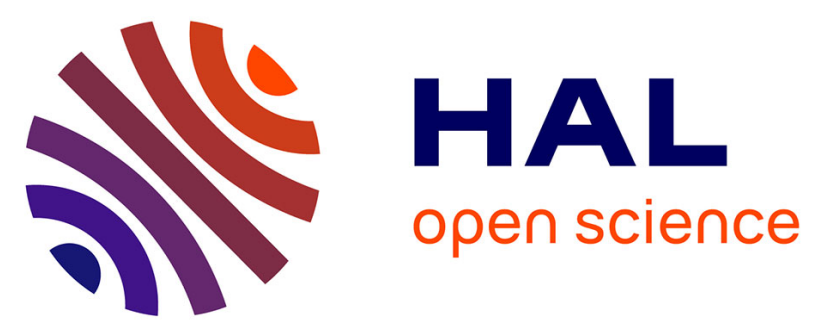

\title{
Atmospheric contribution to cations cycling in highly weathered catchment, Guadeloupe (Lesser Antilles)
}

Celine Dessert, Clémentine Clergue, Alain Maurice Adolphe Antoine

Rousteau, Olivier Crispi, Marc F Benedetti

\section{To cite this version:}

Celine Dessert, Clémentine Clergue, Alain Maurice Adolphe Antoine Rousteau, Olivier Crispi, Marc F Benedetti. Atmospheric contribution to cations cycling in highly weathered catchment, Guadeloupe (Lesser Antilles). Chemical Geology, 2020, 531, pp.119354. 10.1016/j.chemgeo.2019.119354 . hal02403791

\section{HAL Id: hal-02403791 \\ https://hal.science/hal-02403791}

Submitted on 21 Dec 2021

HAL is a multi-disciplinary open access archive for the deposit and dissemination of scientific research documents, whether they are published or not. The documents may come from teaching and research institutions in France or abroad, or from public or private research centers.
L'archive ouverte pluridisciplinaire HAL, est destinée au dépôt et à la diffusion de documents scientifiques de niveau recherche, publiés ou non, émanant des établissements d'enseignement et de recherche français ou étrangers, des laboratoires publics ou privés.

\section{(ㅇ)(1) $\$$}

Distributed under a Creative Commons Attribution - NonCommerciall 4.0 International 
Version of Record: https://www.sciencedirect.com/science/article/pii/S0009254119304838

Manuscript_02a8c8335861da9df874ca1c85adf4ac

1 Atmospheric contribution to cations cycling in highly weathered catchment, Guadeloupe

2 (Lesser Antilles)

3

4 Céline Dessert ${ }^{1, a}$, Clémentine Clergue $^{1}$, Alain Rousteau ${ }^{2}$, Olivier Crispi ${ }^{1, b}$, Marc F. Benedetti $^{1}$

5

6 ' ${ }^{1}$ Université de Paris, Institut de physique du globe de Paris, CNRS, F-75005 Paris, France

7 2'Laboratoire de biologie et de physiologie végétales, UMR EcoFoG, CNRS, Cirad, INRA, Université des

8 Antilles, Université de Guyane, 97159 Pointe-à-Pitre, France

9

10 a corresponding author: E-mail address: dessert@ipgp.fr (Céline Dessert)

11 b present address: Laboratoire d'océanographie biologique, UMR 7621, Laboratoire Arago, BP 44,

1266651 Banyuls-sur-Mer cedex, France

13

14 Keywords: Atmospheric deposit, Saharan dust, cation-nutrient recycling, Sr and $\mathrm{Nd}$ isotopes, Critical

15 Zone.

16

17 Abstract:

18 The important fertilizing role of atmospheric dust, and particularly African dust, in tropical rainforests

19 is increasingly recognized but still poorly quantified. To better evaluate dust input into the Caribbean

20 basin, we sampled critical zone compartments of a small forested volcanic catchment in Guadeloupe

21 (soils, parent rock, atmospheric dust, plants, soil solutions, stream and rain waters). The aims of this 
22 study are to track sources of cation nutrients ( $\mathrm{Ca}, \mathrm{Mg}, \mathrm{K}, \mathrm{Sr}$ ) developed on highly weathered soil in the

23 rainforest of Guadeloupe, to quantify plant recycling of these nutrients, and to identify constraints on

24 regolith development and its associated nutrient pool.

25 In the Quiock Creek catchment, a large isotopic range of ${ }^{87} \mathrm{Sr} /{ }^{86} \mathrm{Sr}$ and $\varepsilon \mathrm{Nd}$ values was observed despite

26 the small scale of observation. Sr isotopic composition of the dissolved load varied from 0.7084 in

27 rainfall to 0.7110 in soil solution, whereas it ranges between 0.7068 and 0.7153 for soil samples and

28 between 0.7096 and 0.7102 for plants. The $\mathrm{Nd}$ isotopic composition varied between -8.39 in near-

29 surface soil samples to 2.71 in deeper soil. All samples had an intermediate signature between that of

30 the bedrock endmember $\left({ }^{87} \mathrm{Sr} /{ }^{86} \mathrm{Sr}=0.7038 ; \varepsilon N d=4.8\right.$ ) and the atmospheric endmember (sea salt:

$31{ }^{87} \mathrm{Sr} /{ }^{86} \mathrm{Sr}=0.7092$ and Saharan dust: $\left.{ }^{87} \mathrm{Sr} /{ }^{86} \mathrm{Sr}=0.7187, \varepsilon \mathrm{Nd}=-11.5\right)$.

32 The regolith was built on pyroclastic deposits, but, because of extreme leaching, the regolith has lost

33 its original bedrock signature and inherited an exogenous atmospheric signature. Our results show that

34 only the chemical weathering of the fresh near-surface minerals can provide nutrients to the ecosystem

35 (first $30 \mathrm{~cm}$ ). However, this dust weathering is too low to sustain the tropical forest ecosystem on its

36 own. The cationic mass balance at the catchment scale, as well as the Sr isotopic signature, show that

37 cation and Sr fluxes are of atmospheric origin only and that original bedrock no longer participates in

38 nutrient cycles. The vegetation reflects the ${ }^{87} \mathrm{Sr} /{ }^{86} \mathrm{Sr}$ of the dissolved pool of atmospheric Sr.

39 At the soil-plant scale, the cation-nutrient fluxes provided by vegetation (litter fall + leaf excretion) are the Quiock Creek catchment.

45 This first characterization of biogeochemical cycles in the Guadeloupean rainforest suggests that the major compared to input and output fluxes. The annual $\mathrm{Ca}, \mathrm{K}, \mathrm{Sr}$ and $\mathrm{Mg}$ fluxes within the vegetation are, respectively, 31, 28, 20 and 3 times greater than the exported fluxes at the outlet of the basin. The residence time of nutrients in the vegetation is 16 years for $\mathrm{K}$ and close to 45 years for $\mathrm{Sr}$, Ca and $\mathrm{Mg}$. These results emphasize the highly efficient vegetative turnover that dominates the nutrient cycle in forest community of Quiock Creek is sustained by a small near-surface nutrient pool disconnected from 
47 the deep volcanic bedrock. We also demonstrated that, even with efficient nutrient recycling, Saharan

48 dust plays a significant role in maintaining ecosystem productivity in Guadeloupe over long-time scales. 


\section{Introduction}

50 The base cations calcium, potassium and magnesium, are nutrient elements essential for plant

51 development as they are building blocks of tissues and chlorophyll and have a number of metabolic

52 functions. They also play a major role in neutralizing soil acidity and maintaining biological activity. In

53 ecosystems, base cations in soils and plants originate from in situ mineral weathering (e.g. Schlesinger,

54 1997). However, numerous studies have shown that, under specific circumstances, these elements can

55 be provided by the atmosphere through precipitation or dust (e.g. Dahms, 1993; Hedin et al., 1994;

56 Kennedy et al., 1998). Forest ecosystems are generally poor in nutrients and many studies have

57 suggested that atmospheric deposits are significant sources of nutrients (e.g. Hedin and Likens, 1996;

58 Okin et al., 2004; Soderberg and Compton, 2007; Pett-Ridge, 2009; Yu et al., 2015; Schuessler et al.,

59 2018). Nutrient depletion in soils is particularly high in tropical areas, where temperature and

60 precipitation combine to intensively leach nutrients from rocks and soil. In such contexts, the soil is

61 usually strongly impacted by atmospheric inputs (e.g. Whipkey et al., 2000; Kurtz et al., 2001; Poszna

62 et al., 2002; Pett-Ridge et al., 2009b). Cation nutrients, essential for plants, are thus expected to be

63 strongly influenced by atmospheric inputs in highly weathered soils. Several studies conducted in

64 Hawaii (Kennedy et al., 1998; Chadwick et al., 1999; Stewart et al., 2001), along chrono- and climato-

65 sequence gradients, have shown that the more soils are leached, the more associated plants are

66 influenced by atmospheric inputs. Other studies conducted in tropical areas of Costa-Rica (Bern et al.,

67 2005; Porder et al., 2006) have shown that the soil-nutrient pool could still be influenced by bedrock

68 weathering. The authors have suggested that rock-derived input was maintained by high erosion rates

69 or deep plant roots.

70 The transport of African dust into the Caribbean basin is relatively well documented, either by

71 measuring contemporary fluxes (e.g. Prospero et al., 1981; Prospero 1999) or by studying Quaternary

72 age geological limestone records found on the western Atlantic islands of Barbados, the Florida Keys,

73 and the Bahamas (e.g. Muhs et al., 1990; 2007). However, the number of soil record studies examining

74 the impact of Saharan dust inputs on nutrient cycling over pedogenic timescales of hundreds to 
thousands of years is limited. Studies conducted in the Luquillo Mountains in Puerto Rico (Pett-Ridge et al., 2009a; McClintock et al., 2015) have revealed that Saharan dust contributes significantly to nutrient inputs into weathered soils. Recent studies (Dessert et al., 2015; Clergue et al., 2015; Fries et al., 2019) have also tended to show that the soils of Guadeloupe can be strongly impacted by atmospheric deposits. These few studies did not take into account internal nutrient cycles in the watershed (e.g. litterfall, leaf excretion) and did not focus on the influence of dust on plants. However, the characterization of these cycles is important from the perspective of ecological theory and the understanding of Earth's Critical Zone.

As it is impossible to directly measure the cation-nutrient flux between rock, soil and vegetation, base cation cycles in forested ecosystems are not straightforward to characterize. Sr and its radiogenic isotopes have been shown to be proxies for cation-nutrient cycling in the atmosphere-soil-plant system (e.g. Capo et al., 1998; Bern et al., 2005; Belanger et al., 2012; Stille et al., 2012). As calcium has a hydrate ionic radius and an ionic charge similar to those of $\mathrm{Sr}$, its behaviour can be deduced from the ${ }^{87} \mathrm{Sr} /{ }^{86} \mathrm{Sr}$ ratio. $\mathrm{K}$ and $\mathrm{Mg}$ chemistry differs from that of $\mathrm{Ca}$ and $\mathrm{Sr}$, but these lithophile elements ultimately originate from the same sources. Their behaviour can be inferred from $\mathrm{Sr}$ isotope data combined with on site element flux calculations. The efficient use of $\mathrm{Sr}$ isotopes as a cation-nutrient cycle proxy necessitates that different $\mathrm{Sr}$ sources exhibit different ${ }^{87} \mathrm{Sr} /{ }^{86} \mathrm{Sr}$ ratios.

In Guadeloupe, possible common sources of Sr and base cation nutrients (volcanic rock, sea salt and Saharan dust) differ in Sr isotopic signature. The ${ }^{87} \mathrm{Sr} /{ }^{86} \mathrm{Sr}$ ratio of volcanic bedrock is between 0.70341 and 0.70382 (White and Patchett, 1984; White and Dupré, 1986). The signature of sea salt is 0.70917 (e.g. Dia et al., 1992) and the ${ }^{87} \mathrm{Sr} /{ }^{86} \mathrm{Sr}$ mean ratio of Saharan dust is 0.71788 (Biscaye et al., 1974; Grousset et al., 1988; Grousset et al., 1992; Rognon et al., 1996; Grousset et al., 1998; Pett-Ridge et al., 2009). We looked at Sr isotopes, Nd isotopes, and base cation nutrients to identify their sources. Like $\mathrm{Sr}, \mathrm{Nd}$ isotope ratios are used to trace $\mathrm{Nd}$ sources, as they are not affected by biological and weathering processes (e.g. Liu et al., 2013). The Nd signature in volcanic rock from Guadeloupe ranges from 3.02 to 5.05 (White and Patchett, 1984; White and Dupré, 1986) and the signature of Saharan dust varies 
101 between -10.5 and -14.5 (Grousset et al., 1992; Dia et al., 2006). Nd and Sr differ in their mobility (Nd

102 is less mobile than $\mathrm{Sr}$ ) and are distributed differently in surface compartments, thus the comparison

103 between these two isotopic systems provides complementary information on constraints in the study

104 area.

105 In this study we report Sr isotope ratios in all compartments of a small catchment (rainfall, throughfall,

106 soil solution, bulk soil, unweathered rock, river water, litter and atmospheric dusts) and Nd isotope

107 ratios of soils and unweathered rock. The catchment is located in the tropical rainforest of Guadeloupe,

108 in the Caribbean (FWI). This area is covered by highly weathered soils built on mono-lithological 109 volcaniclastic deposits. Despite the poverty of the soils (Buss et al., 2010; Clergue et al., 2015), a dense 110 rainforest is developed on it (Rousteau et al., 1994,1996). The aims of this study are to: 1) Track sources

111 of cation nutrients ( $\mathrm{Ca}, \mathrm{Mg}, \mathrm{K}$ ) of the rainforest of Guadeloupe developed on a highly weathered soil;

112 2) Quantify the vegetation recycling of cation nutrients; 3) Identify the origin of "rock-derived" cation-

113 nutrient pool in the soil and give constraints on regolith development.

\section{2. Site description}

116 The studied catchment $\left(16^{\circ} 17^{\prime} \mathrm{N}, 61^{\circ} 70^{\prime} \mathrm{W}\right)$ is located on Basse-Terre Island, the volcanic part of the

117 Guadeloupe archipelago in the French West Indies (Fig. 1). The Quiock Creek drains a watershed of 8

118 ha, ranging from $200 \mathrm{~m}$ to $350 \mathrm{~m}$ in altitude, located in the primary tropical rainforest of the 119 Guadeloupe National Park. The Quiock Creek catchment is monitored by the ObsErA observatory 120 (OZCAR research infrastructure; Gaillardet et al., 2018) dedicated to the study of weathering and 121 erosion processes under tropical climatic conditions (Clergue et al., 2015; Lloret et al., 2016; Fries et 122 al., 2019; Guérin et al., 2019).

123 The climate on site is characterized by high mean annual temperature $\left(25^{\circ} \mathrm{C}\right)$ and precipitation $(3500$

$124 \mathrm{mmyr}^{-1}$ ). The mean annual runoff is $1,130 \mathrm{~mm}$. Evapotranspiration is high, between 60 and $70 \%$ 125 (Clergue et al., 2015; Guérin et al., 2019) and tropical storms and hurricanes contribute significantly to 126 the hydrology of the site (Zahibo et al., 2007). 
Quiock Creek is covered by a very thick ferralitic soil (>15 m thick; Colmet-Daage and Bernard, 1979,

128 IRD soil map) built on Pleistocene andesitic pyroclastic deposits (Boudon et al., 1988). The regolith 129 profile of Quiock Creek mainly consists of secondary minerals, with kaolinite/halloysite as the main 130 mineral ( $95 \%$ by weight of the bulk soil; Buss et al., 2010) and is highly depleted in mobile elements 131 (Buss et al., 2010; Clergue et al., 2015). All these features are characteristic of a highly weathered soil.

132 Despite the high nutrient depletion of these soils, they support a tropical rainforest (Rousteau et al., 133 1996; Van Laere et al., 2016). This rainforest is characterized by three dominant species: Amanoa 134 caribaea Kr. and Urb. (Phyllanthaeae), Tapura latifolia Benth (Dichapetalaceae) and Dracryodes excelsa Vahl (Burseraceae). The litter flux produced by this oldgrowth rainforest was determined each two weeks using 10 litter traps of one square meter size each monitored for two years (2011-2013). Annual

137 litter flux reached $7.8 \mathrm{t} \cdot \mathrm{ha}^{-1} \cdot \mathrm{yr}^{-1}$ of dry matter (Rousteau, 2014), comparable to the rainforest flux in northeastern Puerto Rico (Weaver and Murphy, 1990). The litter production is seasonal, with the highest litter fall occurring in June-August (40\% of the annual litter fall). Finally, the biomass measured on site is equal to 376.8 t.ha-1 (Rousteau, 2014).

141 Atmospheric inputs to the watershed come in two forms: wet deposits and dry deposits. Wet deposits 142 consist of rainfall, while dry deposits include sea salt aerosols, Saharan dust and volcanic ash. Because 143 of the location of the study site in the heart of the National Park, anthropic contributions are negligible.

144 One of the peculiarities of the Caribbean is the major input of Saharan dust (SD) up to $100 \mathrm{~kg}^{-h^{-1}} \cdot \mathrm{yr}^{-1}$ measured in Guadeloupe (J. Molinié, personal communication) which is consistent with amounts reported in the literature for the Caribbean basin (Glaccum and Prospero, 1980; Mahowald et al., 2006;

147 Pett-Ridge et al., 2009; Yu et al., 2015). Throughout the Caribbean region, Saharan dust is deposited on 148 the ground or on the canopy by rain. These dust deposits are mainly composed of mica/illite and quartz 149 (Prospero et al., 1970; Glaccum and Prospero, 1980). For instance, in the Quiock Creek soil profile, the 150 dull aspect of quartz, characteristic of aerial transport, suggests that Saharan dust is likely the source 151 of quartz. 
153 Montserrat, located $86 \mathrm{~km} \mathrm{NW}$ of Guadeloupe. It erupted on July 18, 1995, after a century of 154 quiescence. Since 1995, six recognized ash fall episodes have impacted Guadeloupe (www.mvo.ms; 155 activity report of OVSG 2000). The two most important events took place in September 1996 and 156 February 2010 and produced ash-fall deposits on Guadeloupe that were thicker than $1 \mathrm{~mm}$, 157 corresponding to fluxes of about 50 to $100 \mathrm{~g} \mathrm{~m}^{-2}$ of ash each (Cadelis et al., 2013; OVSG reports). The 158 volcanic ashes were mainly composed of crystalline silica, mostly cristobalite (Baxter et al., 1999).

159 All these atmospheric sources (sea salt and dust) have been shown to highly impact soil in the 160 Caribbean Basin (e.g. Borg and Banner, 1996; Herwitz et al., 1996; Muhs et al., 2009; Pett-Ridge et al., 161 2009; Opfergelt et al., 2012; Clergue et al., 2015; Dessert et al., 2015; Fries et al., 2019).

\section{Sample collection}

All compartments of the watershed were sampled between 2011 and 2013. Water samples consisted of rainfall, throughfall, soil solution and river water, and solid samples consisted of soil, rock, litter and 166 dust.

\section{3.1. Water samples}

We collected water samples during contrasting hydrological periods. River samples ( $Q C, n=39$ ) were

169 collected manually once a month and more frequently during six field trips. Rainfall (RF, $n=9)$, and 170 throughfall (TF, $n=48)$ were sampled during six field trips between 2011 and 2013. They both were 171 collected in polypropylene bottles with a funnel located one meter above the ground in order to avoid 172 contamination from soil particles. Rainfall were collected on site on the roof of the "Maison de la Forêt" 173 (RF-MF) or at the "Observatoire Volcanologique et Sismologique de Guadeloupe" (RF-OVSG). These 174 samples correspond to several rainfall events cumulated over 1 to 5 days, depending on the sample. 175 Throughfall waters were collected by three collectors randomly positioned in the Quiock Creek 176 catchment (collector $n^{\circ} 1$ to $n^{\circ} 3$ ) and were sampled every 1 to 5 days, depending on the sample. Soil 
177 solutions (SS) were sampled using nested tension lysimeters equipped with porous ceramic cups

178 located between 15 and $823 \mathrm{~cm}$ in depth (Buss et al., 2010). These soil solutions were sampled each

179 month and the sampling dates selected for isotopic measurement were 10-26-2012 and 06-28-2013.

180 Conductivity and $\mathrm{pH}$ were measured on site for the Quiock Creek samples and after collection at the

181 OVSG for the other samples. For alkalinity measurements, non-filtered $20 \mathrm{~mL}$ aliquots were used. The

182 remaining water was filtered through $0.2 \mu \mathrm{m}$ cellulose filters and divided into two subsamples. One

183 non-acidified aliquot was stored in polypropylene bottles and used for anion and silica analyses. The

184 second aliquot was acidified $\left(2 \% \mathrm{HNO}_{3}\right)$, stored in polypropylene bottles and used for cation, trace

185 element and $\mathrm{Sr}$ isotope measurements. Strontium isotopic compositions were measured on 26

186 selected samples corresponding to 3 samples of rainfall, 6 samples of throughfall, 4 samples of stream

187 water and 13 samples of soil solution.

188 3.2. Solid samples

189 We analyzed andesite (04-GW-12) and basalt (00-GU-44 and 03-GU-75) samples from Samper et al. 190 (2007) to characterize the unweathered parent rock (Fig. 1). A soil profile ( $n=27)$ was collected with a 191 hand-auger down to 12.5 m depth during lysimeter installation in 2007 (Buss et al., 2010). We collected 192 Saharan dust during a dust event deposit on July 1 and 5, 2013. It corresponds to rainfall particulate 193 matter obtained by filtration on a $0.2 \mu \mathrm{m}$ cellulose filter. The filter was then dried and stored in a Petri 194 dish. We also analysed 5 samples of litter, collected during one of the most productive periods 195 (between June 10 and 24, 2011). "Leaves 1" corresponds to a mixture of litter from different species 196 (collected in the same litter collector) whereas "Leaves 2" corresponds to Amanoa caribaea leaves only. 197 "Branches 1" and "Branches 2" correspond to a mixture of branches collected in two different litter 198 collectors. Finally, "Roots" (April 2012) are from Amanoa caribaea. 
Soil and litter samples were first dried in an oven $\left(60^{\circ} \mathrm{C}\right)$ for 3 days and crushed in an agate mortar (soil

203 samples) or in a ball mill (litter samples). Soil and rock samples (100 mg) were dissolved in a mixture of

$204 \mathrm{HNO}_{3} / \mathrm{HF}$ for 2 days at $120^{\circ} \mathrm{C}$. This mixture was then evaporated and dissolved twice in $2 \mathrm{~mL} 6 \mathrm{~N} \mathrm{HCl}$

205 and finally stored in $1 \mathrm{~N} \mathrm{HCl}$. Saharan dust samples collected on cellulose filters underwent an initial

206 step of filter digestion in diluted $5 \mathrm{~N} \mathrm{HNO}_{3}$ at $100^{\circ} \mathrm{C}$ for 1 day and were treated with the same protocol

207 as for rock and soil samples. Litter samples $(500 \mathrm{mg})$ were first dissolved in $10 \mathrm{~mL}$ of $16 \mathrm{~N} \mathrm{HNO}_{3}$ in 50

$208 \mathrm{~mL}$ Teflon beakers for $24 \mathrm{~h}$ at room temperature and then digested in a DigiPREP block digestion system

209 for another $24 \mathrm{~h}$ at $90^{\circ} \mathrm{C}$. After an evaporation step at $60^{\circ} \mathrm{C}$, the samples were dissolved once more in

$21016 \mathrm{~N} \mathrm{HNO}_{3}$ for $24 \mathrm{~h}$ at $90^{\circ} \mathrm{C}$. Finally, after evaporation, $0.5 \mathrm{~mL} \mathrm{HF} / \mathrm{H}_{3} \mathrm{BO}_{3}$ were added to fully dissolve the

211 phytoliths. These samples were then stored in $50 \mathrm{~mL}$ of $2 \mathrm{~N} \mathrm{HNO}_{3}$.

212 4.2. Major and trace element analyses

213 We measured base cations by ICP AES (Thermofisher iCap 6200 series) at the Institut de Physique du

214 Globe de Paris (IPGP). Anions in soil solutions were measured with a Dionex DX 120 chromatograph at

215 the IPGP and the OVSG/IPGP. We quantified Sr concentrations using HR-ICP-MS (Element II

216 ThermoScientific) at IPGP. The limit of quantification is $20 \mathrm{ppt}$ and repeated measurement of the SLRS-

2175 standard lead to an external reproducibility of $3 \%$.

218 Major elements in solid samples were measured by ICP AES (Thermofisher iCap 6200 series) at the

219 IPGP. Trace elements in solid samples were measured with an ICP-MS X series mass spectrometer

220 (Thermo Electron) at the Institut des Sciences de la Terre de Paris (ISTeP) of the Universite Pierre et

221 Marie Curie. We followed the bracketing method using BEN rock standards for bracketing and BEN,

222 GSN and LKSD2 to validate the measurements. The standard values measured in this study are

223 compared to the certified values to validate the data (Table S1). We measured major element and Sr

224 concentrations in litter samples using a calibration curve, such as for water samples. The accuracy of

225 this measurement was checked by repeated analyses of a vegetation standard NIST SRM 1515.

226 4.3. Sr and Nd purification 
227 Sr and Nd isotope analyses were performed on the Neptune multicollector ICP-MS (Thermo Scientific)

228 at IPGP using the Apex sample inlet system. A prior step of purification is needed in order to avoid a

229 matrix effect during measurement.

230 The separation of Sr from the rest of the matrix was automated for water samples with HPIC (High

231 Performance Ion Chromatography) as fully described in Meynadier et al. (2006). Sr contained in

232 solubilized solid samples was separated from the rest of the matrix on $\mathrm{Sr}-\mathrm{Spec}$ resin in $3 \mathrm{~N} \mathrm{HNO}_{3}$ media.

233 The elution step was performed with milliQ $\mathrm{H}_{2} \mathrm{O}$. The resin was replaced after each separation to avoid

234 memory effects. The purified solution of $\mathrm{Sr}$ was evaporated and dissolved in $0.05 \mathrm{~N} \mathrm{HNO}_{3}$ for isotopic

235 measurement. The minimum amount required for Sr isotopic measurement is 50-100 ng Sr in $1 \mathrm{~mL}$.

236 For Nd separation, a two-step procedure was applied (Richard et al., 1976; Caro et al., 2006). First, rare

237 earth elements were separated from the rest of the matrix on TRU-Spec resin in $2 \mathrm{~N} \mathrm{HNO}_{3}$ media. Then,

238 the separation of the different rare earth elements was performed on $\mathrm{Ln}$-spec resin in $0.25 \mathrm{~N} \mathrm{HCl}$ media.

239 The purified $\mathrm{Nd}$ solution was evaporated and dissolved in $3 \mathrm{~N} \mathrm{HNO}_{3}$ for isotopic measurement. The

240 minimum amount required for $\mathrm{Nd}$ isotopic measurement is $50 \mathrm{ng} \mathrm{Nd}$ in $1 \mathrm{~mL}$.

241 4.4. Sr and $\mathrm{Nd}$ isotope analyses

242 For Sr, the method used corresponds to the measurement of 100 ratios of 4 second iteration time per

243 sample or standard. Mass interferences with $\mathrm{Kr}$ (84 and 86) were corrected using ${ }^{83} \mathrm{Kr} /{ }^{84} \mathrm{Kr}$ and ${ }^{83} \mathrm{Kr} /{ }^{86} \mathrm{Kr}$,

244 measured in the blank at the beginning of each session. Mass interference with Rb (87) was corrected

245 using the ${ }^{85} \mathrm{Rb} /{ }^{87} \mathrm{Rb}$ ratio measured in a low concentrated $\mathrm{Rb}$ solution (2.5 ppb) after Kr measurement.

246 The mass bias was corrected using the ${ }^{86} \mathrm{Sr} /{ }^{88} \mathrm{Sr}$ ratio of 0.1194 . Each measurement was normalized to

247 the NBS value certified as ${ }^{87} \mathrm{Sr} /{ }^{86} \mathrm{Sr}=0.71025$, which was measured every 3 samples. The standard error

248 based on repeated measurement of the NBS standard was $2 \%=0.00001$.

249 The $\varepsilon N d$ was calculated relative to the CHUR (Chondritic Uniform Reservoir) as follows:

$250 \quad \varepsilon \mathrm{Nd}=\left(\frac{{ }^{143} \mathrm{Nd} /{ }^{144} \mathrm{Nd}_{\text {Sample }}}{{ }^{143} \mathrm{Nd} /{ }^{144} \mathrm{Nd}_{\mathrm{CHUR}}}-1\right) \times 10000$ 
251 The CHUR value is 0.512638 (Jacobsen and Wasserburg, 1980). The method used corresponds to the

252 measurement of 100 ratios of 4 second iteration time per sample or standard. Mass interferences with

$253 \mathrm{Sm}(144,148$ and 150$)$ were corrected using ${ }^{147} \mathrm{Sm} /{ }^{144} \mathrm{Sm}=4.83870$. The mass bias was corrected using

254 the ${ }^{146} \mathrm{Nd} /{ }^{144} \mathrm{Nd}$ ratio of 0.72190 . Each measurement was normalized to the NIST value certified as $255{ }^{143} \mathrm{Nd} /{ }^{144} \mathrm{Nd}=0.511418 \pm 6 \cdot 10^{-6}$ (Caro et al., 2006), which was measured every 3 samples. The external 256 error was $0.18 \varepsilon(2 \sigma)$.

257 4.5. Cation flux and residence time calculation

258 Elemental fluxes were obtained by multiplying the water/matter flux by the mean concentrations or 259 determined from the following equations. Water fluxes were determined in Clergue et al. (2015). 260 Throughfall water flux is $3079 \mathrm{~mm} \mathrm{yr}^{-1}$. The Quiock Creek discharge ranges between 150 and $400 \mathrm{~L} \mathrm{~min}^{-}$

$261{ }^{1}$ with a mean value of $172 \mathrm{~L} \mathrm{~min}^{-1}$, corresponding to a runoff of $1130 \mathrm{~mm} \mathrm{yr}^{-1}$. Dry matter litter flux 262 reaches $7.8 \mathrm{t} \mathrm{ha}^{-1} \mathrm{yr}^{-1}$ (Rousteau 2014).

263 Throughfall elementary fluxes $\left(\mathrm{F}_{\mathrm{TF}}\right)$ are described by equation 2 , where $\mathrm{F}_{\mathrm{EX}}$ is the flux of cations exuded 264 by plants, and $F_{R F}$ the rainfall flux.

$265 \mathrm{~F}_{\mathrm{TF}}=\mathrm{F}_{\mathrm{EX}}+\mathrm{F}_{\mathrm{RF}}$

266 The rainfall compartment is influenced by both sea salt aerosols $\left(F_{S W}\right)$ and Saharan dust leaching ( $\left.F_{S D}\right)$ 267 and $F_{R F}$ is equal to:

$268 \mathrm{~F}_{\mathrm{RF}}=\mathrm{F}_{\mathrm{SW}}-\mathrm{F}_{\mathrm{SD}}$

269 We consider that the flux of $\mathrm{Cl}$ in throughfall $\left(\mathrm{F}-\mathrm{Cl}_{\mathrm{TF}}\right)$ is exclusively from rainfall. $\mathrm{F}_{\mathrm{RF}}$ is determined from 270 the $\mathrm{F}-\mathrm{Cl}_{\mathrm{TF}}$ and $(\mathrm{X} / \mathrm{Cl})$ rainfall ratios:

$271 \quad \mathrm{~F}_{\mathrm{RF}}=\mathrm{F}-\mathrm{Cl}_{\mathrm{TF}} \times(\mathrm{X} / \mathrm{Cl})_{\mathrm{RF}}$

272 with $\mathrm{Na} / \mathrm{Cl}_{\mathrm{RF}}=0.63, \mathrm{Ca} / \mathrm{Cl}_{\mathrm{RF}}=0.09, \mathrm{Mg} / \mathrm{Cl}_{\mathrm{RF}}=0.09, \mathrm{~K} / \mathrm{Cl}_{\mathrm{RF}}=0.05 ; 1000 \mathrm{Sr} / \mathrm{Cl}_{\mathrm{RF}}=0.56$ (mean mass ratio 273 determined from rainfall data; see following section) 
274 and $F_{E X}$ is equal to:

$275 \quad F_{E X}=F_{T F}-F_{R F}$

276 Assuming that all the $\mathrm{Cl}$ flux in throughfall has a sea salt origin, we used $\mathrm{F}-\mathrm{Cl}_{\mathrm{TF}}$ and $\mathrm{X} / \mathrm{Cl}$ sea salt ratios

$277\left(\mathrm{Na} / \mathrm{Cl}_{\mathrm{sw}}=0.86, \mathrm{Ca} / \mathrm{Cl}_{\mathrm{sw}}=0.02, \mathrm{Mg} / \mathrm{Cl}_{\mathrm{sw}}=0.10, \mathrm{~K} / \mathrm{Cl}_{\mathrm{sw}}=0.02,1000 \mathrm{Sr} / \mathrm{Cl}_{\mathrm{sw}}=0.16\right.$ and mass ratio from

278 Brewer et al., 1975) to determine $F_{s w}$ for each cation:

$279 \quad \mathrm{~F}_{\mathrm{SW}}=\mathrm{F}-\mathrm{Cl}_{\mathrm{TF}} \times(\mathrm{X} / \mathrm{Cl})_{\mathrm{SW}}$

280 and $F_{S D}$ is equal to:

$281 \quad F_{S D}=F_{R F}-F_{S W}$

282 The vegetation flux $\left(F_{V E G}\right)$ is described by equation 8 , where $F_{E X}$ is the flux of cations exuded by plants,

283 and $F_{L F}$ the litter fall flux.

$284 \mathrm{~F}_{\mathrm{VEG}}=\mathrm{F}_{\mathrm{EX}}+\mathrm{F}_{\mathrm{LF}}$

285 The standing stock of cations in the forest (Stock) is determined from biomass (376.8 t.ha ${ }^{-1}$; Rousteau

286 et al., 2014) and mean cationic concentrations into plants. The residence time ( $\left.T_{\text {res }}\right)$ of each element in

287 the vegetation is determined by the following equation:

$288 \mathrm{~T}_{\text {res }}=$ Stock $/ \mathrm{FVEG}_{\mathrm{VE}}$

290 5. Results

291 All the compartments of the catchment were characterized for their element concentrations and

292 isotopic compositions. Table 1 presents results of major elements and Sr concentrations only in water

293 samples for which Sr isotopic composition was measured. A full list of the concentrations of major

294 cations we have used in this paper are taken from Clergue et al. (2015) of which the range in 
compositions for solid samples are presented in Table 3.

\subsection{Atmospheric samples}

298 The $\mathrm{pH}$ of rainfall ranged from 4.1 to 5.7 (Clergue et al., 2015). The major cation in rainfall was Na, 299 whose concentration varied between 41 and $165 \mu \mathrm{mol} / \mathrm{L}$. The mean concentration of $\mathrm{K}$, $\mathrm{Ca}$ and $\mathrm{Mg}$ were 4, 7 and $12 \mu \mathrm{mol} / \mathrm{L}$, respectively. Sr concentration ranged from 9 and $39 \mathrm{nmol} / \mathrm{L}$ (Table 2S) and Sr isotopic composition varied between 0.70841 and 0.71029 (Fig. 2). These data were in agreement with previously published data in the Puerto Rican and Guadeloupean rainforests (Gioda et al., 2013; Dessert et al., 2015).

The concentrations of major elements in Saharan dust collected in Guadeloupe, were higher than those in the soil samples (except for Al and Fe; see Clergue et al., 2015) and lower than in the rock samples (Table 3). The average values for Ca (1830 ppm), Na (940 ppm) and K (5300 ppm) were lower than those reported in the literature for dust samples collected in West Africa ( $>2600 \mathrm{ppm}$ for Ca and $\mathrm{Na},>9800$ ppm for K; Moreno et al., 2006). Mg concentrations around 5200 ppm were in the range of those reported in the literature (> 4600 ppm; Moreno et al., 2006). The concentration of Sr concentration was around 50 ppm, 1.5 to 5 times lower than the values reported in the literature for dust samples

311 (Moreno et al., 2006) and 10 times higher than soil Sr concentrations. Concerning Sr isotopic data, the 312 dust samples were the most radiogenic of all samples collected on the site. The isotopic signature, around 0.7187, is consistent with previous estimations and measurements (Biscaye et al., 1974;

314 Grousset et al., 1988; Grousset et al., 1992; Rognon et al., 1996) which gave a value of 0.7179 for 315 Saharan dust in the Caribbean (Pett-Ridge et al., 2009b).

\subsection{Throughfall samples}

317 The $\mathrm{pH}$ of the throughfall was slightly higher than that of the rainfall, ranging from 5.1 to 6.3 (Clergue 318 et al., 2015). The major cation in the throughfall was $\mathrm{Na}$, whose concentration varied between 17 and $319264 \mu \mathrm{mol} / \mathrm{L}$ (Table 2). Mean concentration of K, Ca and Mg were 39, 17 and $17 \mu \mathrm{mol} / \mathrm{L}$ respectively. Sr 
3210.70953 and 0.70978 (Table 1, Fig. 2). These data were in agreement with the ranges published in the

322 literature for tropical rainforests (e.g. Forti and Neal, 1992; McDowell, 1998).

323 The $\mathrm{K} / \mathrm{Cl}$ ratio in throughfall was ten times higher than the $\mathrm{K} / \mathrm{Cl}$ ratio in rainfall, attesting to a strong

324 enrichment of $\mathrm{K}$ in throughfall (Fig. 3). To a lesser extent, $\mathrm{Sr}, \mathrm{Ca}$ and $\mathrm{Mg}$ were also enriched in 325 throughfall. The enrichment of throughfall compared to rainfall indicates that these elements are 326 partially released by plants. This exudation process has been largely described in the literature 327 (Vitousek and Sanford, 1986; Dezzeo and Chacon, 2006).

328 Throughfall is slightly more radiogenic than sea salt (Fig. 2). This observation can be explained by a 329 mixture in throughfall of sea salt $\mathrm{Sr}$ and $\mathrm{Sr}$ from Saharan dust leachates or plant exudates. It is 330 impossible to distinguish between the two latter sources only on the basis of Sr isotopes.

\section{5.3. Litter samples}

332 Major element concentrations in litter samples were very different from concentrations in the other 333 solid samples (Table 3). The most abundant element in the litter was $\mathrm{Ca}$, with concentrations ranging 334 between 1 and 3\%. This is more than 100 times the Ca concentration in the soil and is similar to the 335 parent rock Ca concentration. The $\mathrm{K}$ concentration, intermediate between 0.1 and $1.1 \%$, and the $\mathrm{Mg}$ 336 concentration, ranging between 0.2 and $0.6 \%$, were also higher than the $\mathrm{K}$ and $\mathrm{Mg}$ concentrations in 337 the soil. These concentrations are consistent with values in the literature for litter samples (e.g. Liao et 338 al., 2006; Riotte et al., 2014). Similarly, the Sr concentration in the litter varied from 80 to 200 ppm, which is one or two orders of magnitude higher than the $\mathrm{Sr}$ concentration in the soil (up to $13 \mathrm{ppm}$ ). The isotopic signature of the litter varied between 0.70966 and 0.71019 (Fig. 2). This signature differed

341 from the ${ }^{87} \mathrm{Sr} /{ }^{86} \mathrm{Sr}$ ratio of local bedrock, but was similar to that of samples of vegetation growing on

342 highly depleted volcanic soil as reported in the literature (Whipkey et al., 2000; Stewart et al., 2001;

343 Chadwick et al., 2009).

$344 \quad 5.4$. Soil solution samples 
345 The soil solutions were acidic, with $\mathrm{pH}$ values ranging from 4.2 to 5.4 . This can be explained by the low 346 cation content, which plays a key role in neutralizing the acidity of soil solutions. $\mathrm{Na}$ and $\mathrm{Cl}$ were the

347 most abundant elements, with mean concentrations of $179 \mu \mathrm{mol} / \mathrm{L}$ and $199 \mu \mathrm{mol} / \mathrm{L}$, respectively (Table

348 2). Average $\mathrm{Mg}, \mathrm{K}$ and Ca concentrations were 24, 5 and 3 respectively. Sr concentrations in soil

349 solutions ranged between 7 and $101 \mathrm{nmol} / \mathrm{L}$ (Table S2), and isotopic composition varied between

3500.70996 and 0.71097 (Table 1). Soil solutions were more radiogenic than local rocks and sea salts,

351 attesting to an exogenous source of Sr in the soil solution (Fig. 2). In superficial soil horizons (up to 90 $\mathrm{cm}), \mathrm{Sr}$ concentrations were systematically higher than in the deeper horizons (mean value of 53 and $16 \mathrm{nmol} / \mathrm{L}$ respectively). To a lesser extent, $\mathrm{Ca}$ and $\mathrm{Mg}$ were also slightly higher in superficial horizons than in the deepest. On the contrary, K concentrations were constant over the entire soil profile.

Fig. 3 shows the cation concentrations normalized to $\mathrm{Cl}$ for all dissolved samples. $\mathrm{Na} / \mathrm{Cl}$ ratios were relatively homogeneous in all water samples and close to the sea salt ratio. In general, soil solutions were depleted in nutrient cations compared to throughfall. This was particularly true for K, which was probably due to efficient $K$ uptake by plant root systems and microorganisms in the first few centimeters of soil. As previously noted, soil solutions of superficial horizons were slightly enriched in $\mathrm{Sr}$, Ca and Mg compared to deeper soil solutions, which indicates a potential atmospheric source of cations. It was even observed that the surface solutions were sometimes enriched in Mg with respect

362 to throughfall.

\subsection{Soil and rock samples}

364 The soil profile is characterized by a very high proportion of secondary minerals $(95 \%$ wt. of secondary 365 minerals and 70 \%wt. of kaolinite and halloysite; Buss et al., 2010). The chemical composition of the 366 soil indicated that it was highly depleted in mobile cations compared to unweathered rock in 367 Guadeloupe (Table 3). For example, the Ca concentration varied from 23 to 306 ppm, which corresponds to about $100 \%$ depletion compared to volcanic rock, which contains $4.85 \%$ to $7.45 \%$ of Ca.

369 Sr concentration in soil varied between 2 and 13 ppm and was very low compared to unweathered rock 
370 (Table 3). To correct for dilution effects and volume change, $\mathrm{Sr}$ concentration in the soil samples was

371 normalized to an immobile element (Ti). Fig. 4 presents mass transfer coefficient $(\tau)$ values for Sr:

$372 \mathrm{TSr}=\left[(\mathrm{Sr} / \mathrm{Ti})_{\text {soil }} /(\mathrm{Sr} / \mathrm{Ti})_{\text {rock }}\right]-1$

$373 \mathrm{TSr}$ was negative, representing the depletion of $\mathrm{Sr}$ in soil compared to unweathered rock. Sr had a

374 depletion rate of around $98 \pm 2 \%$. The soil profile was systematically less depleted in its first $15 \mathrm{~cm}$ and

375 at depths of $305 \mathrm{~cm}, 427 \mathrm{~cm}, 1219 \mathrm{~cm}$ and $1250 \mathrm{~cm}$. These depths corresponded to horizons enriched

376 in quartz and K-feldspar.

377 The entire profile was more radiogenic $(0.70677-0.71527)$ than the unweathered volcanic rock

378 sampled in Guadeloupe (Fig. 2 and 4). Quartz horizons exhibited the highest Sr isotopic ratio. This

379 observation attests of exogenic source(s) of Sr to the soil. The $\varepsilon N d$ of the profile varied between -8.39

380 and 2.44 and was different from unweathered rock ranging from 4.34 to 5.45 (Table 3). The $\mathrm{Nd}$

381 signature of the quartz horizons was very negative and attested again of an exogenic contribution of

$382 \mathrm{Nd}$ to the profile.

383 5.6. Quiock Creek water samples

384 Conductivity in Quiock Creek ranged from 22.5 to $68.2 \mu \mathrm{S}$ and pH was acidic, ranging from 4.3 to 5.9

385 (see Clergue et al., 2015). The major cation was Na, with a mean concentration of $234 \mu \mathrm{mol} / \mathrm{L}$. Mean

386 concentrations of $\mathrm{K}, \mathrm{Ca}$ and $\mathrm{Mg}$ were 5,10 and $29 \mu \mathrm{mol} / \mathrm{L}$, respectively (Table 2 ). Sr concentration

387 ranged from 35 and $70 \mathrm{nmol} / \mathrm{L}$ (Table S2) and Sr isotopic composition varied between 0.70922 and

$388 \quad 0.70939$.

389

390 6. Discussion

391 6.1. Vegetation cycling

392 6.1.1. Impact of atmospheric deposits on the cation-nutrient budget 
A key question is to what extent atmospheric deposition (wet and dry) impacts the forest's nutrient source. Many biogeochemical studies have shown that $\mathrm{Sr}$, and particularly the ${ }^{87} \mathrm{Sr} /{ }^{86} \mathrm{Sr}$ isotopic ratio, is a good tracer of ecosystem Ca sources (e.g. Capo et al., 1998; Bern et al., 2005; Belanger et al., 2012; Stille et al., 2012; Pett-Ridge et al., 2009a). K and Mg chemistry differs from Ca and Sr, but these lithophilic elements ultimately originate from the same sources. It is therefore possible to acquire some qualitative information on the cycles of these elements using Sr as a proxy.

The internal water cycle of our basin is relatively homogeneous from a Sr isotopic point of view, with a mean ${ }^{87} \mathrm{Sr} /{ }^{86} \mathrm{Sr}$ ratio of 0.7097 for throughfall and 0.7104 for soil solutions (up to 12 meters deep; Fig. 2). This shows that the dissolved pool of $\mathrm{Sr}$ is dominated by sea salts $\left({ }^{87} \mathrm{Sr} /{ }^{86} \mathrm{Sr}\right.$ value equal to 0.7092$)$, with a small influence of more radiogenic sources coming from Saharan dust leaching (Fig. 2). Note also that the Sr isotopic composition of litter of 0.7099 is in the range of that of the dissolved pool of Sr. This has already been well described in several studies, which have shown that vegetation exhibits the signature of the exchangeable Sr pool (e.g. Kennedy et al., 1998; Poszwa et al., 2002). Our results emphasize that atmospheric inputs contribute significantly to actively cycled Sr in the Quiock Creek basin. This hypothesis is consistent with the literature for similar contexts with highly depleted volcanic soils and strong atmospheric input (e.g. Whiptkey et al., 2000; Stewart et al., 2001; Chadwick et al., 2009; Schuessler et al., 2018). As an example, Pett-Ridge et al. (2009a) reported that the proportions of foliar Sr derived from sea salt and dust vary between $33 \%$ and $59 \%$ in the Puerto Rican rainforest. Similarly, in the Quiock Creek catchment, the ${ }^{87} \mathrm{Sr} /{ }^{86} \mathrm{Sr}$ of litter is slightly more radiogenic than sea salt aerosols, emphasizing the influence of Saharan Sr on the ecosystem.

Based on the Sr isotopic composition, the weathering of local volcanic rock seems not to contribute in the plant $\mathrm{Sr}$ pool. It can be deduced that this is also true for the $\mathrm{Ca}, \mathrm{K}$ and $\mathrm{Mg}$ pools. This observation is consistent with the idea that tropical forests developed on highly nutrient-depleted soils derive their nutrients from superficial atmospheric sources and from litter recycling (Jordan, 1982). It may be for this reason that surface soil solutions are slightly less depleted in cations than deeper solutions (>91 cm; Fig. 3), reflecting the cationic inputs of throughfall, dust leaching/weathering and litter 

of Quiock Creek.

421 Tropical forests are largely described as dependent on atmospheric sources, as observed in this study,

422 but they are also known to recycle nutrients very efficiently. In the following section, we calculate the vegetation fluxes in the catchment and estimate the cation-nutrient recycling fluxes.

\section{6.1.2. Vegetation cycling at the soil-plant profile scale}

425 Nutrients contained in plants are released during leaf excretion, litter leaching and litter 426 decomposition. These bio-available elements are partly taken up by the vegetation from the soil

427 solution and, therefore, are recycled. The proportion of nutrients recycled by plants depends on the 428 amounts of available nutrients in the soil. As an example, the study by Holmden and Belanger (2010) 429 shows that in a Boreal forest ecosystem, the proportion of recycled Ca from litter fall can represent 430 from $80 \%$ and $90 \%$ of the annualized Ca inputs to the forest Ca cycle. The authors also note that the proportion of recycled Ca increases with decreasing weathering flux.

432 The internal-cationic fluxes calculated in the Quiock Creek catchment are summarized in Table 4 and

433 Fig. 5. The vegetation flux (FVEG) varies between $8.4 \mathrm{~kg} \cdot \mathrm{ha}^{-1} \cdot \mathrm{yr}^{-1}$ for Na and $141.5 \mathrm{~kg} . \mathrm{ha}^{-1} \cdot \mathrm{yr}^{-1}$ for Ca and 434 represents the biggest elemental flux, except for $\mathrm{Na}$. These results are in agreement with those of the 435 review by Proctor et al. (1987) on primary rainforests and the study by McDowell (1998) in a Puerto 436 Rican rainforest. For $\mathrm{Ca}, \mathrm{Mg}$ and $\mathrm{Sr}$, most of the vegetation flux is provided by litter fall. Concerning $\mathrm{K}$, 437 its flux provided by leaf excretion $\left(41.2 \mathrm{~kg} \cdot \mathrm{ha}^{-1} \cdot \mathrm{yr}^{-1}\right)$ is twice as abundant as the litter fall flux (20.9 kg.ha-

$438{ }^{1} \cdot \mathrm{yr}^{-1}$ ). This confirms that canopy leaching is the main source of $\mathrm{K}$ for the top soil (e.g. McDowell 1998; 439 Riotte et al., 2014). Finally, the Na flux released by vegetation is relatively weak compared to rainfall 440 flux. $\mathrm{Na}$ is not a nutrient for plants and it exhibits conservative behaviour when rainwater passes 441 through the canopy. We note that for $\mathrm{Sr}, \mathrm{K}, \mathrm{Ca}$, and, to a lesser extent $\mathrm{Mg}$, plant recycling is highly 442 efficient. The vegetation flux (FVEG) of Sr, K, and Ca are respectively, 20, 28 and 31 times greater than 443 flux exported at the outlet of the basin (FQC). The vegetation flux of $\mathrm{Mg}$ is 3 times greater than the flux 
445 leaching and thus the nutrient pool derived from weathering minerals. In the tropical context of our

446 study, it is not surprising to observe such a high turnover, because of the nutrient paucity in soils. The

447 same range of solute turnover has been measured in the tropical watershed of Mule Hole in India

448 (Riotte et al., 2014), where vegetation recycling fluxes represented 10-15 times the exported fluxes.

449 More recently, in a tropical watershed in Sri Lanka, Schuessler et al. (2018) estimated this recycling

450 factor between 2 and 7 for $\mathrm{Mg}, 3$ and 10 for $\mathrm{Ca}$ and 9 and 29 for $\mathrm{K}$.

451 Rousteau et al. (2014) have shown that vegetation in the Quiock Creek catchment is at equilibrium with

452 respect to carbon. If the ecosystem is close to equilibrium, the nutrient fluxes taken up would be equal

453 to FVEG (litter fall + leaf excretion). Numerous studies (e.g. Proctor, 1987) have shown that in tropical

454 rainforests, decomposition is invariably rapid and that litter turnover takes less than a year. Even though

455 we did not measure the decomposition rate of litter, our field observations confirm the speed of this

456 process. From the standing stocks of cations in the forest and the annual-cationic FVEG fluxes (Table

457 4), we determined the residence time (Tres) of each element in the vegetation. The element presenting

458 the shortest residence time in the vegetation is $\mathrm{K}$, namely 16 years. This residence time is consistent 459 with the 10 year period determined for K in Puerto Rican forest (McDowell 1998). This short residence 460 time is justified by the fact that $\mathrm{K}$ is one of the most important elements for plant metabolism (as a 461 catalytic agent for carbohydrate synthesis and the transfer of other nutrients) and is abundantly 462 excreted by the leaves. For other elements, the residence time is slightly longer than those determined 463 for $\mathrm{K}$ : 44.6 years for $\mathrm{Sr}, 44.9$ for $\mathrm{Ca}, 45.7$ for $\mathrm{Mg}$ and 48.2 for $\mathrm{Na}$. These results highlight that vegetation 464 recycling dominates the nutrient cycle, and, in light of the Sr isotopic signature, we can deduce that 465 these nutrients have the particularity of being initially of atmospheric origin. Therefore, the Quiock Creek ecosystem is sustained by a little near-surface nutrient pool, which seems disconnected from the 467 deep bedrock.

468 Our study is a first step in the characterization of biogeochemical cycles at the plant-soil scale in the 469 Guadeloupean rainforest. To better characterize and quantify the nutrient recycling, it would be useful 
470 for example, to study the seasonality of vegetation fluxes, investigate the $\mathrm{N}$ and $\mathrm{P}$ cycles, or use the

471 isotopic fractionations of the elements involved in these biogeochemical processes (Ca, Mg, Si, B,...).

472 6.2. Soil cation-nutrient pool and weathering

473 6.2.1. Origin of cation-nutrient pool in the soil

474 After studying geochemical cycles at the plant-soil scale, it is necessary to study the soil profile to

475 determine whether soil is still able to provide nutrients to the forest.

476 In the entire soil profile (Fig. 2), the Sr isotopic signature of the solid phase is high relative to rock,

477 which is consistent with exogenous contributions of Sr. Fig. 6 presents the Sr isotopic signature of soil

478 as a function of the $\mathrm{Sr}$ depletion rate ( $\mathrm{\tau Sr}$ ). The more the sample is rich in $\mathrm{Sr}$, the more the soil $\mathrm{Sr}$

479 signature is radiogenic. This implies that the main source enriching the soil in Sr is more radiogenic than

480 bedrock. The two potential sources of Sr that could enrich the soil in radiogenic Sr are: 1) Sea salts with

481 a signature of 0.70917 (Dia et al., 1992) or 2) Saharan dust with a signature of 0.7187 (this study). This

482 indicates that the soils are so leached that they have almost lost their original rock signature and have

483 inherited an exogenous atmospheric signature. As previously discussed (Section 5.5) at depths of 15,

$48430,305,427,1219$ and $1250 \mathrm{~cm}$, the high ${ }^{87} \mathrm{Sr} /{ }^{86} \mathrm{Sr}$ ratios (> 0.712) are correlated with the highest

485 primary mineral content (Quartz + Feldspar), which could correspond to different dust deposit

486 horizons. All the other soil samples are not enriched in primary minerals but, nevertheless, are

487 characterized by $\mathrm{Sr}$ isotopic ratios that indicate a mixture of bedrock and exogenous atmospheric

488 sources. This indicates that Sr derived from atmospheric deposits is transferred to the soil exchangeable

489 pool and may be incorporated into secondary minerals. This recycled Sr in the soil exchangeable pool

490 could be taken up by plants and reinforces the hypothesis that the nutrients involved in the Quiock

491 Creek ecosystem are of atmospheric origin. This strong atmospheric influence on the soil profile has

492 been described in the study by Clergue et al. (2015), devoted to Li dynamic in the same catchment. The

$493 \delta^{7}$ Li measured in the soil profile also indicated that atmospheric deposition (wet and dry) was a main

494 source of $\mathrm{Li}$ in the bulk soil. 
Because both wet and dry atmospheric deposits are sources of radiogenic $\mathrm{Sr}$, it is not possible to

discriminate between sea salt and Saharan sources in soil only on the basis of the ${ }^{87} \mathrm{Sr} /{ }^{86} \mathrm{Sr}$ ratio.

497 Coupled with $\mathrm{Sr}$ isotopes, Nd isotopes are useful for identifying the different contributions to the soil

498 profile. For example, $\varepsilon N d$ of rock ranges from 4.34 to 5.45 (Table 3 ) and $\varepsilon N d$ of Saharan dust ranges

499 from -10.5 to -14.5 (Grousset et al., 1992; Dia et al., 2006; Scheuvens et al., 2013; McClintok et al.,

500 2015). Sea salt exhibits an extremely low Nd concentration and Saharan dust input seems to be the

501 only atmospheric contribution able to shift the isotopic composition of the soil. The Nd isotopic composition of soil varies between -8.39 and 2.71 and could be explained by a mixture of rock and dust endmembers. The quartz-feldspar horizons are characterized by very negative $\varepsilon \mathrm{Nd}$, indicating a strong Saharan Nd contribution. The amount of quartz and Nd isotopes provide two independent proxies of long-term dust additions to the soil profile. The superficial horizon (the first 30 centimetres) is a contemporary depositional surface while the other horizons attest to past deposition. The deepest quartz horizons $(305,427,792$ and $1219-1250 \mathrm{~cm})$ may represent paleo-surfaces of dust deposits, interspersed between multiple events of volcanic deposition. The variable thickness of these horizons may be partly explained by a physical soil mixing process resulting from bioturbation.

In Fig. 7, the soil samples are plotted in a two-component mixing diagram for ${ }^{87} \mathrm{Sr} /{ }^{86} \mathrm{Sr}$ versus $\varepsilon \mathrm{Nd}$. The

511 curvature of the different mixing lines depends on the $\mathrm{Sr} / \mathrm{Nd}$ ratio of each endmember. The dotted

512 curve represents the mixing line between the unweathered rock endmember $\left({ }^{87} \mathrm{Sr} /{ }^{86} \mathrm{Sr}=0.7038, \varepsilon \mathrm{Nd}\right.$

$513=4.8, \mathrm{Sr} / \mathrm{Nd}=17.9 ;$ from this study and the andesite Nd content of $16 \mathrm{ppm}$ from Taylor and McLennan $5141985)$ and the Saharan endmember $\left({ }^{87} \mathrm{Sr} /{ }^{86} \mathrm{Sr}=0.7187, \varepsilon \mathrm{Nd}=-11.5, \mathrm{Sr} / \mathrm{Nd}=3.4\right.$; from this study and 515 Grousset et al., 1998). This mixing line cannot explain the isotopic composition of the soil samples, 516 indicating that dust is not mixed with fresh rock but with a Sr-depleted weathered rock. Four mixing 517 lines with depleted rock endmembers are shown on Fig. 7. Their Sr/Nd ratios decreased from 10 to 0.1 518 in the most depleted case.

519 If we first consider soil horizons enriched in quartz-feldspar, this mixing model confirms that these 520 particular layers are strongly influenced by the dust endmember. It also emphasized that the 
521 proportion of Saharan Sr in the soil decreases with depth, from $65 \%$ in the first $15 \mathrm{~cm}$, to $20 \%$ in the

522 deepest quartz-feldspar horizons. Finally, our results show that the degree of rock depletion also

523 increases with depth. Indeed, surface horizons (15 and $30 \mathrm{~cm}$ ) can be explained by mixing of dust with

524 moderately depleted rock $(10<\mathrm{Sr} / \mathrm{Nd}<5)$ whereas the deeper horizons involve a mixture with a very

525 depleted rock $(\mathrm{Sr} / \mathrm{Nd}<1)$. The superficial volcanic rock signature is inherited from the deposit of volcanic

526 ashes in Guadeloupe linked to very recent activity of neighbour volcano Soufriere Hills on Montserrat

527 (Baxter et al., 1999; Cadelis et al., 2013). The accumulation of Saharan dust in the upper soil is also

528 observed in quartz-diorite and volcaniclastic soils in Puerto Rico (McClintock et al., 2015), which is too

529 far from the volcanic arc of the Lesser Antilles to be impacted by recent ash deposits. In Puerto Rico,

530 the calculated soil dust content ranges between 0 and $8 \%$, and $\mathrm{Nd}$ from dust in the upper $20 \mathrm{~cm}$ of soil

531 ranges between 0 and 92\% (McClintock et al., 2015), which is consistent with what we have observed

532 in Guadeloupe.

533 If we now consider soil horizons non-enriched in quartz-feldspar, we note that their isotopic

534 composition still reflects a slight influence of the dust endmember and that they have ${ }^{87} \mathrm{Sr} /{ }^{86} \mathrm{Sr}$ ratios

535 close to those of rainfall or that are slightly more radiogenic. The rock Sr isotope signature in these

536 horizons has been completely overprinted by the atmospheric signature (rainfall and dust-derived Sr).

537 The slight influence of dust on the $\mathrm{Nd}$ signature in the entire soil profile is clear evidence for the 538 mobilization of dust-derived $\mathrm{Nd}$ and its redistribution in the soil. This is especially the case for the 539 horizons at depths of 61 and $91 \mathrm{~cm}$, which do not contain quartz and felspar, but whose $\mathrm{Sr}$ and Nd 540 isotope signatures are strongly influenced by the dust endmember (25 to $35 \%$ ). It is possible that the

541 Sr and $\mathrm{Nd}$ come from the leaching of Saharan minerals contained in the upper soil and that are

542 reincorporated into the deeper soil levels. Even if $\mathrm{Nd}$ mobility is much lower than Sr mobility, it seems

543 to increase under extreme leaching conditions. This mobilization of dust-derived Nd into highly

544 weathered soil profiles has been observed in Puerto Rico, where the Nd isotope signature of Saharan

545 dust has been observed noted at depths of 2 and $3 \mathrm{~m}$ (Pett-Ridge et al., 2009b). Our mixing model

546 cannot explain all the data because of the influence of a third end-member, namely sea salt Sr derived 
547 from rainwater. Because sea salts are not a significant source of $\mathrm{Nd}$, the addition of sea salts does not

548 influence the $\mathrm{Nd}$ isotopic composition of soil. Except for the dust horizons, andesitic and dust-derived

549 Sr have been leached extensively and the sea salt Sr signature dominates in the entire profile.

550 In the Quiock Creek catchment, we observe a strong impact of atmospheric sources on the evolution

551 of the chemical composition of the soil with depth and with time. Elements are continuously provided

552 at the surface by fresh dust minerals on a highly depleted soil. Then, we observe a "reversed"

553 weathering profile, with the horizon the most enriched in primary minerals (Saharan and volcanic) and

554 having the strongest andesitic isotopic signature at the top of the soil profile. The impact of 555 atmospheric sources on volcanic soil has been demonstrated in different tropical contexts. In a soil

556 chronosequence in Hawaii, it was shown that the older the soils, the bigger the impact of atmospheric

557 inputs (Kennedy et al., 1998; Whiptkey et al., 2000; Kurtz et al., 2001; Chadwick et al., 2009). Saharan

558 dust was shown to affect soil composition in Puerto Rico (Pett-Ridge et al., 2009b; McClintock et al.,

559 2015) and in Mount Cameroon (Dia et al., 2006). In Guadeloupe, Mg and Li isotopes reflect the 560 influence of sea salt and dust on soil (Opfergelt et al., 2012; Clergue et al., 2015; Fries et al., 2019). Our 561 study supports these prior observations and the need to fully account for these inputs when studying 562 weathering and cation-nutrient cycling under tropical climatic conditions.

563 6.2.2. Does chemical weathering provide elements to the catchment flux?

564 The comparison between rainfall fluxes and output flux from Quiock Creek provides information on 565 processes taking place in the soil. Elementary budgets (output flux - input flux) are negative (Fig. 5).

566 This may mean that the catchment stores cation nutrients in the soil or in the vegetation. However, it

567 can also mean that for these elements, inputs from rainfall are underestimated. In fact, their mean

568 concentrations in rain are highly variable and hard to estimate. In any case, it means that these

569 elements are not enriched as they move through the soil and thus there is no weathering flux for these

570 elements in the catchment. The Sr isotopic composition of Quiock Creek, which is close to the sea salt

571 aerosol signature, supports the idea that the Sr comes from atmospheric input only (Fig. 5). The fact 
572 that the Quiock Creek ${ }^{87} \mathrm{Sr} /{ }^{86} \mathrm{Sr}$ ratio is very different from the volcanic rock signature, indicates that

573 the local rock no longer contributes to the weathering flux. The absence of weathering flux in the

574 Quiock Creek catchment and its peculiar Sr isotopic composition are linked with the intense weathering

575 of the soil, which is highly depleted in major elements (Clergue et al., 2015). This situation is peculiar

576 in Guadeloupe, as in all other catchments studied, the weathering flux is equivalent, or even twice as

577 high, as the rainfall flux (Dessert et al., 2015). This situation is also peculiar in the Caribbean, for

578 example in Puerto-Rico, where numerous catchments are surveyed by the USGS. In the Puerto-Rican

579 catchments, which are subject to the same climate and are covered by rainforest, soils are not as

580 depleted as in Guadeloupe (e.g. Ferrier et al., 2010). The Rio Icacos basin in Puerto Rico is the site of

581 the highest measured chemical solute fluxes for a catchment on granodiorite (Turner et al., 2003).

582 Clergue et al. (2015) showed that in this catchment, part of the weathering flux of Li originates from

583 the main secondary mineral dissolution (i.e. kaolinite). Using the kaolinite dissolution rate (Carroll et

584 al., 1988), the authors showed that kaolinite dissolution can explain the weathering flux of Li measured

585 on site. The same calculations were made for Mg and Sr, using the average concentration of those

586 elements in kaolinite. They show that kaolinite can provide $\mathrm{Mg}$ and $\mathrm{Sr}$ by dissolution, with a respective

587 flux of $0.012 \mathrm{~kg}_{\mathrm{Mg}} \mathrm{ha}^{-1} \mathrm{yr}^{-1}$ and $0.002 \mathrm{~kg}_{\mathrm{Sr}} \mathrm{ha}^{-1} \mathrm{yr}^{-1}$. However, these fluxes are much lower than the

588 rainfall fluxes and consistent with the absence of measurable weathering flux for some major elements 589 and Sr. 
591 In the Quiock Creek catchment, a large range of ${ }^{87} \mathrm{Sr} /{ }^{86} \mathrm{Sr}$ and $\varepsilon N d$ values is observed despite the small 592 scale of observation. Sr isotopic composition varies from 0.70677 in deep bulk soil samples to 0.71882 593 in dust samples. The Nd isotopic composition varies just as much, between -8.39 in near-surface soil 594 samples to 2.71 in deeper soil (732 cm depth). For the Saharan dust endmember, we used a mean $\varepsilon N d$ 595 value of -11.5 , determined from the literature. These large isotopic ranges, coupled with major and 596 trace elements, have helped to better understand nutrient dynamic in tropical ecosystems in 597 Guadeloupe.

598 The regolith profile was built on pyroclastic deposits, but, because of extreme leaching, it has almost lost its original andesitic signature and inherited an exogenous atmospheric signature. Only Saharan dust is likely to have influenced the Nd balance throughout the entire $12 \mathrm{~m}$-thick profile, while the $\mathrm{Sr}$ balance is influenced by both Saharan dust and sea salt aerosols. Sr and Nd isotopes, combined with mineralogy and mobile element concentrations in the regolith, argue for a multi-layered soil profile which has been built by successive volcaniclastic episodes, separated by periods of dust deposition. Deep horizons enriched in quartz-felspar are then interpreted as paleo-soils impacted by Quaternary 605 Saharan dust deposits, whereas the near-surface soil horizon is currently impacted by fresh dust 606 deposits. Our results show that only the chemical weathering of the near-surface fresh minerals can 607 provide nutrients to the ecosystem, the deeper regolith $(>30 \mathrm{~cm})$ being nutrient depleted. However, 608 this dust weathering flux is too low to sustain the tropical forest ecosystem.

609 The cationic mass balance at the catchment scale and the Sr isotopic signature of Quiock Creek indicate

610 that cation and Sr fluxes are of atmospheric origin. Thus, in this highly weathered catchment, the 611 original andesitic bedrock no longer participates in the weathering fluxes of Quiock Creek. This 612 conclusion leads us to question the notion of "bedrock" in catchment involving on a deep weathered 613 formation. Is it still an andesitic bedrock or is it now a lateritic bedrock? 
614 The dissolved Sr cycle at the catchment scale is mainly dominated by sea salts, with a small contribution

615 of Sr coming from the Saharan dust leaching. The vegetation exhibits the signature of the dissolved

616 pool of Sr, indicating that the nutrient pool derives from atmospheric inputs.

617 At the soil-plant scale, the cation-nutrient fluxes provided by vegetation (litter fall + leaf excretion) are

618 major compared to input and output fluxes. The Ca, K, Sr and Mg fluxes each year in the vegetation

619 are, respectively, 31, 28, 20 and 3 times greater than the exported fluxes at the outlet of the basin. The

620 residence time of nutrients in vegetation is 16 years for $\mathrm{K}$ and close to 45 years for $\mathrm{Sr}, \mathrm{Ca}$ and $\mathrm{Mg}$. These

621 results emphasize the highly efficient plant turnover that dominates the nutrient cycle in the Quiock

622 Creek catchment.

623 This first characterization of biogeochemical cycles in a Guadeloupean forest suggests that the forest

624 community of Quiock Creek is sustained by a small near-surface nutrient pool, disconnected from the

625 deep andesitic bedrock.

626

627 Acknowledgements

628 This work has been financially supported by the INSU-CNRS and the Région Guadeloupe. Parts of this

629 work were supported by the IPGP multidisciplinary program PARI and by the Paris-IdF region SESAME

630 Grant no. 12015908. This work could not have been done without logistical support from 1) both INSU-

631 CNRS observatories in Guadeloupe run by the IPGP: the Observatoire de I'Eau et de I'Erosion aux

632 Antilles (OBSERA) and the Observatoire Volcanologique et Sismologique de Guadeloupe (OVSG) and,

633 2) the Parc National de Guadeloupe (PNG). We thank in particular N. Liagre, M. Valy and F. Bastaraud

634 from PNG for their assistance with the field work. We also thank X. Quidelleur and P. Lahitte (Paris Sud

63511 University) for providing us with rock samples from Guadeloupe. Major element concentrations

636 from water and solid samples were measured by L. Cordier and C. Gorge. Thanks are extended to B.

637 Caron from IsTeP-UPMC and J.-L. Birck, A. Cogez, L. Faure, A. Michel, M. Tharaud from IPGP for their 638 analytical assistance. The equipment and services of the Laboratoire de biologie et de physiologie 
639 végétale de l'Université des Antilles was used for the biological and ecological aspects of the study. We

640 thank M. Daullet for his assistance in the laboratory. Special thanks to V. Virapin, who processed and

641 weighed most of the collected litter samples and E. Mira who made and placed the litter traps. This

642 study greatly benefited from comments from A. Cogez, M. Dulormne, F. Bussière, J. Molinié and R.

643 Losno. We gratefully acknowledge Susan Johnson for her helpful comments on the original version of

644 this paper. We have a special thought for our colleague and friend Agnès Michel, who passed away in

645 2018. She was involved in the solid sample analyses and was always keen to develop new analytical

646 experiments. We gratefully acknowledge two anonymous reviewers and the editor for their helpful and

647 critical comments on the original manuscript. IPGP contribution \# 4079. 
649 Baxter, P.J., Bonadonna, C., Dupree, R., Hards, V.L., Kohn, S.C., Murphy, M.D., Nichols, A., Nicholson, R. 650 A., Norton, G., Searl, A., Sparks, R.S.J., Vickers, B.P., 1999. Cristobalite in volcanic ash of Soufriere Hills 651 Volcano, Monserrat. British West Indies. Science 283, 1142-5.

652 Bélanger, N., Holmden, C., Courchesne, F., Côté, B., Hendershot, W.H., 2012. Constraining soil mineral 653 weathering $87 \mathrm{Sr} / 86 \mathrm{Sr}$ for calcium apportionment studies of deciduous forest growing on soils 654 developed from granitoid igneous rocks. Geoderma 185-186, 84-96.

655 Bern, C.R., Townsend, A.R., Lang Farmer, G., 2005. Unexpected dominance of Parent-materiel strontium 656 in a tropical forest on highly weathered soils. Ecology 86, 626-632.

657 Biscaye, P. E., Chesselet, R., Prospero, J. M., 1974. Rb-Sr, 87Sr/86Sr isotope system as an index of provenance of continental dusts in the open Atlantic Ocean. Journal de Recherches Atmospheriques 8 , $659819-829$.

660 Borg, L.E., Banner, J.L., 1996. Neodymium and strontium isotopic constraints on soil sources in 661 Barbados, West Indies. Geochim. Cosmochim. Acta 60 (21), 4193-4206.

662 Boudon, G., Dagain, J., Semet, M. P., Westercamp, D., 1988. Le massif volcanique de la Soufrière 663 (département de la Guadeloupe, Petites Antilles). In: BRGM (Ed.), Carte géologique au 1/20.000ème.

664 Brewer, P. G., Riley, J. P., Skirrow, C. (1975) Chemical oceanography. Academic Press, New York,1, 417.

665 Buss H.L., White A.F., Dessert C., Gaillardet J., Blum A.E., Sak P.B., 2010. Depth profiles in a tropical 666 volcanic critical zone observatory: Basse-Terre, Guadeloupe. In: Torres-Alvarado, I.S., Birkkle, P. (Eds.), 667 Proceedings of the 13th International conference on water-Rock Interaction. Taylor \& FrancisGroup, 668 London, UK. 
670 West Indies) and volcanic eruption in Montserrat (70 km from Guadeloupe). Revue des Maladies

671 Respiratoires 30, 203-214.

672 Capo, R.C., Stewart, B.W., Chadwick, O.A., 1998. Strontium isotopes as tracers of ecosystem processes:

673 theory and methods. Geoderma 82, 197-225.

674 Caro, G., Bourdon, B., Birck, J.L., Moorbath, S., 2006. High-precision ${ }^{142} \mathrm{Nd} /{ }^{144} \mathrm{Nd}$ measurements in

675 terrestrial rocks: constraints on the early differentiation of the Earth's mantle. Geochim. Cosmochim.

676 Acta $70(1), 164-191$.

677 Carroll-Webb, S. A., \& Walther, J. V. (1988) A surface complex reaction model for the pH-dependence

678 of corundum and kaolinite dissolution rates. Geochi. Cosmochim. Acta 52 (11), 2609-2623.

679 Chadwick, O. A., Derry, L. A., Vitousek, P. M., Huebert, B. J., Hedin, L. O., 1999. Changing sources of 680 nutrients during four million years of ecosystem development. Nature 397(6719), 491-497.

681 Chadwick, O. A., Derry, L. A., Bern, C. R., Vitousek, P. M., 2009. Changing sources of strontium to soils 682 and ecosystems across the Hawaiian Islands. Chem. Geol. 267(1), 64-76.

683 Clergue, C., Dellinger, M., Buss, H. L., Gaillardet, J., Benedetti, M.F., Dessert, C., 2015. Influence of 684 atmospheric deposits and secondary minerals on Li isotopes budget in a highly weathered catchment, 685 Guadeloupe (Lesser Antilles). Chem. Geol. 414, 28-41.

Colmet-Daage, F., Bernard, Z., 1979. Contribution à l'Atlas des départements d'Outre-mer: Guadeloupe.

687 Carte des sols de la Guadeloupe, Grande-Terre, Marie-Galante. Carte des pentes et du modelé de la 688 Guadeloupe, Grande-Terre, Marie-Galante. ORSTOM, Antilles.

689 Cuevas, E., Lugo, A.E., 1998. Dynamics of organic matter and nutrient return from litterfall in stands of 690 ten tropical tree plantation species. Forest Ecology and Management 112, 263-279. 
691 Dahms, D.E., 1993. Mineralogical evidence for eolian contribution to soils of late quaternary moraines,

692 Wind River Mountains, Wyoming, USA. Geoderma, 59, 175-196.

693 Dessert, C., Lajeunesse, E., Lloret, E., Clergue, C., Crispi, O., Gorge, C., Quidelleur, X., 2015. Controls on 694 chemical weathering on a mountainous volcanic tropical island: Guadeloupe (French West Indies). 695 Geochim. Cosmochim. Acta 171, 216-237.

696 Dezzeo, N., Chacon, N., 2006. Nutrient fluxes in incident rainfall, throughfall, and stemflow in adjacent 697 primary and secondary forests of the Gran Sabana, southern Venezuela. Forest ecology and 698 management 234, 218-226.

699 Dia, A., Chauvel, C., Bulourde, M., Gérard, M., 2006. Eolian contribution to soils on Mount Cameroon: 700 Isotopic and trace element records. Chem. Geol. 226, 232-252.

701 Dia, A. N., Cohen, A. S., O'Nions, R. K., Shackleton, N. J., 1992. Seawater Sr isotope variation over the 702 past 300 kyr and influence of global climate cycles. Nature 356, $786-788$.

703 Ferrier, K.L., Kirchner, J.W. Riebe, C.S., Finkel, R.C., 2010. Mineral-specific chemical weathering rates 704 over millennial timescales: measurements at Rio Icacos, Puerto Rico. Chem. Geol. 277 (1-2), 101-114. Forti, M. C., Neal, C., 1992. Hydrochemical cycles in tropical rainforests: an overview with emphasis on central Amazonia. Journal of Hydrology 134(1), 103-115.

707 Fries D.M., James, R.H., Dessert, C., Bouchez, J., 2019. The response of Li and Mg isotopes to rain events 708 in a highly-weathered catchment. Chem. Geol. 519, 68-82.

709 Gaillardet J., Braud I., Hankard F., et al., 2018. OZCAR: The French Network of Critical Zone 710 Observatories. Vadose Zone Journal, 17, doi:10.2136/vzj2018.04.0067.

711 Gioda, A., Mayol-Bracero, O.L., Scatena, F.N., Weathers, K.C., Mateus, V.L., McDowell, W.H., 2013. 712 Chemical constituents in clouds and rainwater in the Puerto Rican rainforest: Potential sources and 713 seasonal drivers. Atmospheric Environment 68, 208-220. 

Geol. 37, 295-321.

717 in marine sediments and aerosols: North Atlantic. Earth Planet. Sci. Lett. 87, 367-378.

718 Grousset, F. E., Rognon, P., Coudé-Gaussen, G., Pédemay, P., 1992. Origins of peri-Saharan dust deposits 719 traced by theit Nd and Sr isotopic composition. Palaeogeogr. Palaeoclimatol. Palaecoecol. 93, 203-212. wind regimes traced by the Sr-Nd isotopic composition of subtropical Atlantic sediments: last glacial maximum vs today. Quaternary Science Reviews 17, 395-409.

Guérin, A., Devauchelle, O., Robert, V., Kitou, T., Dessert, C., Quiquerez, A., Allemand, P., Lajeunesse, E., 2019. Stream-discharge surges generated by groundwater flow. Geophysical Research Letters, doi: 10.1029/2019GL082291. Hedin, L.O., Granat, L., Likens, G.E., Adri Buishand, T., Galloway, J.N., Butler, T.J., Rodhe, H., 1994. Steep declines in atmospheric base cations in regions of Europe and North America. Nature 367, 351-354. long-term patterns of rainfall and throughfall nutrient fluxes in a subtropical wetforest in Puerto Rico. Journal of Hydrology 333, 472-485. 
738 (3), 647-654.

Kennedy, M. J., Chadwick, O. A., Vitousek, P. M., Derry, L. A., Hendricks, D. M., 1998. Changing sources of base cations during ecosystem development, Hawaiian Islands. Geology 26(11), 1015-1018.

Kurtz, A. C., Derry, L. A., Chadwick, O. A., 2001. Accretion of Asian dust to Hawaiian soils: isotopic, elemental, and mineral mass balances. Geochim. Cosmochim. Acta 65(12), 1971-1983. return of uplifted coral reef tropical forest. Forest ecology and management 235(1), 174-185. the composition of the continental crust: Insights from Li and $\mathrm{Nb}$ isotopes in bauxite profiles developed on Columbia River Basalts. Geochim. Cosmochim. Acta 115, 73-91.

Lloret E., C. Dessert, H. L. Buss, C. Chaduteau, S. Huon, P. Alberic, Benedetti M.F., 2016. Sources of dissolved organic carbon in small volcanic mountainous tropical rivers, examples from Guadeloupe (French West Indies) Geoderma 282, 129-138.

Mahowald, N.M., Muhs, D.R., Levis, S., Rasch, P.J., Yoshioka, M., Zender, C.S., Luo, C., 2006. Change in 752 atmospheric mineral aerosols in response to climate: last glacial period, pre-industrial, modern, and 753 doubled carbon dioxide climates. J. Geophys. Res.-Atmos. 111 (D10).

754 McClintock, M.A., Brocard, G., Willenbring, J., Tamaya, C., Porder, S., Pett-Ridge, J.C., 2015. Spatial 755 variability of African dust in soils in a montane tropical landscape in Puerto Rico. Chem. Geol. 412, 6975681.

757 McDowell, W.H., 1998. Internal nutrient fluxes in a Puerto Rican rain forest. Journal of Tropical Ecology $758 \quad 14,521-536$. 
761 Moreno, T., Querol, X., Castillo, S., Alastuey, A., Cuevas, E., Herrmann, L., Mounkaila, M.,Elvira, J., 762 Gibbons, W., 2006. Geochemical variations in aeolian mineral particles from the Sahara-Sahel Dust 763 Corridor. Chemosphere 65, 261-270.

764 Muhs, D.R., Bush, C.A., Stewart, K.C., Rowland, T.R., Crittenden, R.C., 1990. Geochemical evidence of 765 Saharan dust parent material for soils developed on Quaternary limestones of Caribbean and Western 766 Atlantic islands. Quaternary Research 33, 157-177.

767 Muhs, D.R., Budahn, J., Prospero, J.M., Carey, S.N., 2007. Geochemical evidence for African dust inputs 768 to soils of western Atlantic islands: Barbados, the Bahamas and Florida. J. Geophys. Res. 112, F02009. 769 Okin, G.S., Mahowald, N., Chadwick, O.A., Artaxo, P., 2004. Impact of desert dust on the 770 biogeochemistry of phosphorus in terrestrial ecosystems. Glob. Biogeochem. Cycles 18, GB2005.

771 Opfergelt, S., Georg, R.B., Delvaux, B., Cabidoche, Y.M., Burton, K.M., Halliday, A.N., 2012. Mechanisms 772 of magnesium isotope fractionation in volcanic soil weathering sequences, Guadeloupe. Earth Planet. 773 Sci. Lett. 341-344, 176-185.

774 OVSG-IPGP Website. Volcano and seismic activity bulletin of La Soufrière of Guadeloupe. 775 http://www.ipgp.fr/fr/ovsg/observatoire-volcanologique-sismologique-de-guadeloupe.

776 Pett-Ridge, J.C., 2009. Contributions of dust phosphorus cycling in tropical forests of the Luquillo 777 Mountains, Puerto Rico. Biogeochemistry 94, 63-80.

778 Pett-Ridge, J.C., Derry, L.A., Barrows, J.K., 2009a. Ca/Sr and ${ }^{87} \mathrm{Sr} /{ }^{86} \mathrm{Sr}$ ratios as tracers of Ca and Sr cycling 779 in the Rio Icacos watershed, Luquillo Mountains, Puerto Rico. Chem. Geol. 267(1), 32-45. 
781 inputs in a tropical granitoid watershed, Luquillo Mountains, Puerto Rico. Geochim. Cosmochim. Acta $78273,25-43$.

783 Porder, S., Clark, D.A., Vitouseck, P.M., 2006. Persistence of rock-derived nutrients in the wet tropical 784 forests of La Selva, Costa Rica. Ecology 87, 594-602.

785 Poszwa, A., Dambrine, E., Ferry, B., Pollier B., Loubet, M., 2002. Do deep tree roots provide nutrients 786 to the tropical rainforest? Biogeochemistry 60, 97-118.

787 Proctor, J., 1987. Nutrient cycling in primary and old secondary rainforests. Applied Geography 7, 135788152.

789 Prospero, J.M., 1999. Long-term measurements of the transport of African mineral dust to the 790 southeastern United States: implications for regional air quality. Journal of Geophysical Research 104, $791 \quad 15917-15927$.

Prospero, J.M., Bonatti, E., Schubert, C., Carlson, T.N., 1970. Dust in Caribbean atmosphere traced to an African dust storm. Earth Planet. Sci. Lett. 9, 287-290.

Prospero, J.M., Glaccum, R.A., Nees, R.T., 1981. Atmospheric transport of soil dust from Africa to South 795 America. Nature 289, 570-572.

796 Schlesinger, W.H., 1997. Biogeochemistry: an analysis of global change. Academic Press, San Diego, 797 California, USA.

798 Richard, P., Shimizu, N., Allègre, C.J., 1976. 143 Nd/146Nd, a natural tracer: an application tooceanic 799 basalts. Earth Planet. Sci. Lett. 31 (2), 269-278.

800 Riotte, J., Marechal, J. C., Audry, S., Kumar, C., Bedimo, J. B., Ruiz, L., ... \& Braun, J. J., 2014. Vegetation 801 impact on stream chemical fluxes: Mule Hole watershed (South India). Geochim. Cosmochim. Acta 145, $802 \quad 116-138$. 
804 deposition on the Cape Verde Islands: sedimentological and Nd-Sr isotopic evidence. Sedimentology $80543,359-366$.

Rousteau, A., 1996. Structures, flores, dynamiques: réponses des forêts pluviales des Petites Antilles

807 aux milieux montagnards. In: Guillaumet, J.L., Belin, M., Puig, H. (Eds.), Phytogéographie Tropicale:

808 Réalités et Perspectives. ORSTOM, Paris, pp. 307-321.

809 Rousteau, A., Dessert, C., Dulormne, M., 2014. Bilan des travaux réalisés dans le cadre du projet 810 "Vulnérabilité des écosystèmes insulaires guadeloupéens aux changements climatiques". Région 811 Guadeloupe funding.

812 Rousteau, A., Portecop, J., Rollet, B., 1994. Carte écologique de la Guadeloupe. Université Antilles813 Guyane, ONF, Conseil Général, Parc National de la Guadeloupe, Guadeloupe.

814 Samper, A., Quidelleur, X., Lahitte, P., Mollex, D., 2007. Timing of effusive volcanism and collapse events 815 within an oceanic arc island: Basse-Terre, Guadeloupe archipelago (Lesser Antilles Arc). Earth Planet. 816 Sci. Lett. $258,175-191$.

817 Schuessler, J.A., von Blanckenburg, F., Bouchez, J., Uhlig, D., Hewawasam, T., 2018. Nutrient cycling in 818 a tropical montane rainforest under a supply-limited weathering regime traced by elemental mass 819 balances and Mg stable isotopes. Chem. Geol. 497, 74-87.

820 Soderberg, K., Compton, J.S., 2007. Dust as a Nutrient Source for Fynbos Ecosystems, South Africa. 821 Ecosystems 10, 550-561.

822 Stewart, B. W., Capo, R. C., Chadwick, O. A., 2001. Effects of rainfall on weathering rate, base cation 823 provenance, and Sr isotope composition of Hawaiian soils. Geochim. Cosmochim. Acta 65(7), 10878241099.

825 Stille, P., Schmitt, A.-D., Labolle, F., Pierret, M.-C., Gangloff, S., Cobert, F., Lucot, E., Guéguen, F., Brioschi, 826 L., Steinmann, M., Chabaux, F., 2012. The suitability of annual tree growth rings as environmental 
827 archives: Evidence from $\mathrm{Sr}, \mathrm{Nd}, \mathrm{Pb}$ and $\mathrm{Ca}$ isotopes in spruce growth rings from the Strengbach

828 watershed. C. R. Geoscience 344, 297-311.

829 Taylor, S.R. and McLennan, S.M., 1985. The Continental Crust: Its Composition and Evolution. Blackwell,

830 Oxford, $1-312$.

831 Turner, B. F., Stallard, R. F., \& Brantley, S. L., 2003. Investigation of in situ weathering of quartz diorite

832 bedrock in the Rio Icacos basin, Luquillo Experimental Forest, Puerto Rico. Chem. Geol. 202, 313-341.

833 Van Laere, G., Gall, Y. and Rousteau, A., 2016. The forest Ecosystems Observatory in Guadeloupe (FWI).

834 Caribbean Naturalist, Special Issue $n^{\circ} 1:$ 108-115.

835 Vitousek, P. M., Sanford, R. L., 1986. Nutrient cycling in moist tropical forest. Annu. Rev. Ecol. Syst. 17, 836 137-167.

837 Weaver, P.L., Murphy, P.G., 1990. Forest structure and productivity in Puerto Rico's Luquillo Mountains. 838 Biotropica $22(1), 69-82$

839 Whipkey, C. E., Capo, R. C., Chadwick, O. A., Stewart, B. W., 2000. The importance of sea spray to the

840 cation budget of a coastal Hawaiian soil: a strontium isotope approach. Chem. Geol. 168(1), 37-48.

841 White, W.M., Dupré, B., 1986. Sediment subduction and magma genesis in the Lesser Antilles: isotopic 842 and trace element constraints. J. Geophys. Res. 91, 5927-5941.

843 White, W.M., Patchett, J., 1984. Hf-Nd-Sr isotopes and incompatible element abundances in island arcs; 844 implications for magma origins and crust-mantle evolution. Earth and Planetary Science Letters 67, 845 167-185.

846 Wilcke, W., Velescu, A., Leimer, S., Bigalke, M., Boy, J., Valarezo, C., 2017. Biological versus geochemical 847 control and environmental change drivers of the base metal budgets of a tropical montane forest in 848 Ecuador during 15 years. Biogeochemistry 136, 167-189. 
849 Xu, Y., Losno, R., Dessert, C., Monna, F., Robert, V., Chane-Teng, J., 2017. Compositional analysis of 850 Saharan dust input to Guadeloupe (FWI). Goldschmidt Conference, Paris, 2017 August 13-18, $85116 \mathrm{~d} / 3045$

852 Yu, H., Chin, M., Yuan, T., Bian, H., Remer, L.A., Prospero, J.M., Omar, A., Winker, D., Yang, Y., Zhang, Y., 853 Zhang, Z., Zhao, C., 2015. The fertilizing role of African dust in the Amazon rainforest: A first multiyear 854 assessment based on data from Cloud-Aerosol Lidar and Infrared Pathfinder Satellite Observations. 855 Geophys. Res. Lett. 42, 1984-1991.

856 Zahibo, N., Pelinovsky, E., Talipova, T., Rabinovich, A., Kurkin, A., Nikolkina, I., 2007. Statistical analysis 857 of cyclone hazard for Guadeloupe, Lesser Antilles. Atmos. Res. 84, 13-29. 
859

860

861

862

871 to be immobile and illustrates the extreme depletion of Sr in the soil compared to unweathered rock

872 (values closed to -1 ).

Fig. 1. The Quiock Creek catchment $\left(16^{\circ} 17^{\prime} \mathrm{N}, 61^{\circ} 70^{\prime} \mathrm{W}\right)$ in the Guadeloupe National Park. The MF rain gauge is located in a clearing, on the roof of the "Maison de la Forêt", and the OVSG rain gauge is located on the roof of the observatory. The soil profile was sampled during lysimeter installation (see Buss et al., 2010).

Fig. 2. Sr isotopic composition of dissolved and solid samples collected in the Quiock Creek catchment. Sea salt Sr isotopic ratio $=0.70917$ (Dia et al., 1992); volcanic rock $=0.7038$ (this study); Saharan dust $=0.7187$ (this study).

Fig. 3. Molar ratios ( $\mu \mathrm{mol} / \mu \mathrm{mol}$ ratios, except for the $\mathrm{Sr} / \mathrm{Cl}$ ratio expressed in $\mathrm{nmol} / \mu \mathrm{mol}$ ) of dissolved load in the different compartments of the Quiock Creek catchment. RF: rainfall, TF: throughfall, SS: soil solution (above and below $91 \mathrm{~cm}$ depth), QC: Quiock Creek, SW: seawater/sea salt.

Fig. 4. Soil profiles. Quartz + feldspar content (from Buss et al., 2010), mass transfer coefficient $(\tau)$ for $\mathrm{Sr}$ in soil samples relative to bedrock, and isotopic signature of $\mathrm{Sr}$ and $\mathrm{Nd} . \tau$ is calculated considering $\mathrm{Ti}$ Fig. 5. Cation fluxes in the Quiock Creek catchment expressed in kg/ha/yr. FSW is the sea salt flux, FSD

874 the Saharan dust leaching flux, FRF the rainfall flux, FTF the throughfall flux, FLF the litter fall flux, FEX 875 the leaf excretion flux and FQC the Quiock Creek flux.

876 Fig. 6. Sr mass transfer coefficient as a function of Sr isotopic ratio in soil samples. Sea salt Sr isotopic 877 ratio $=0.70917$ (Dia et al., 1992); volcanic rock $=0.7038$ (this study); Saharan dust $=0.7187$ (this study). 878 Samples enriched in quartz-feldspar are symbolized by white square.

879 Fig. 7. Two-component mixing diagram of $\varepsilon N d$ vs. Sr isotopic ratio in soil samples. Horizon depths (cm) 880 are added and samples enriched in quartz-feldspar are symbolized by white squares. The solid lines 
881 represent different mixing curves between a bedrock (fresh and depleted) end-member and a "Saharan

882 dust" end-member. The mixing proportions are expressed in \% of dust Sr. The black dotted curve

883 represents a mixture of fresh rock $\left({ }^{87} \mathrm{Sr} /{ }^{86} \mathrm{Sr}=0.7038, \varepsilon \mathrm{Nd}=4.8, \mathrm{Sr} / \mathrm{Nd}=17.9\right)$ and dust $\left({ }^{87} \mathrm{Sr} /{ }^{86} \mathrm{Sr}=\right.$

$8840.7187, \varepsilon N d=-11.5, \mathrm{Sr} / \mathrm{Nd}=3.4)$. The other curves show a mixture between of depleted rock $\left({ }^{87} \mathrm{Sr} /{ }^{86} \mathrm{Sr}\right.$

$885=0.7038, \varepsilon \mathrm{Nd}=4.8, \mathrm{Sr} / \mathrm{Nd}$ varying from 10 to 0.1 for the most depleted rock) and dust. The samples

886 are explained by a mixture of Saharan dust and depleted rock. The soil horizons enriched in quartz-

887 feldspar are strongly influenced by dust (20 to $65 \%$ of dust $\mathrm{Sr}$ ). The near-surface horizon (first $30 \mathrm{~cm}$ ) is

888 the most impacted by dust and can be explained by the mixing of dust with moderately depleted rock.

889 This emphasizes the contemporary, or very recent, deposition of both Saharan dust and volcanic ash in

890 Guadeloupe (recent volcanic activity of nearby Montserrat). The deeper quartz-feldspar horizons are

891 paleo-surfaces of dust deposits interspersed with volcanic deposits. With time, andesitic and dust-

892 derived Sr has been leached extensively and the sea salt Sr signature dominates today in the entire

893 profile. 


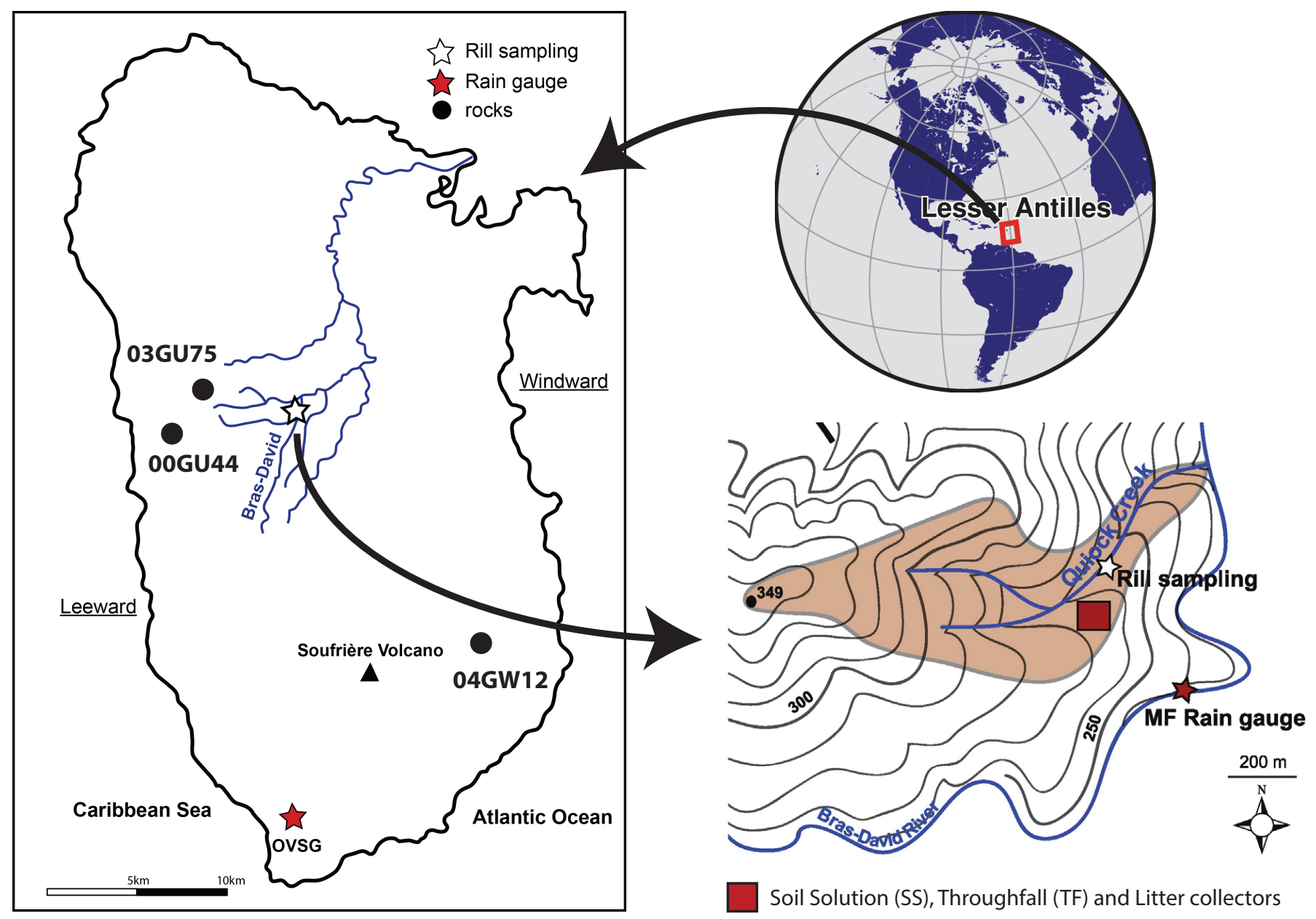




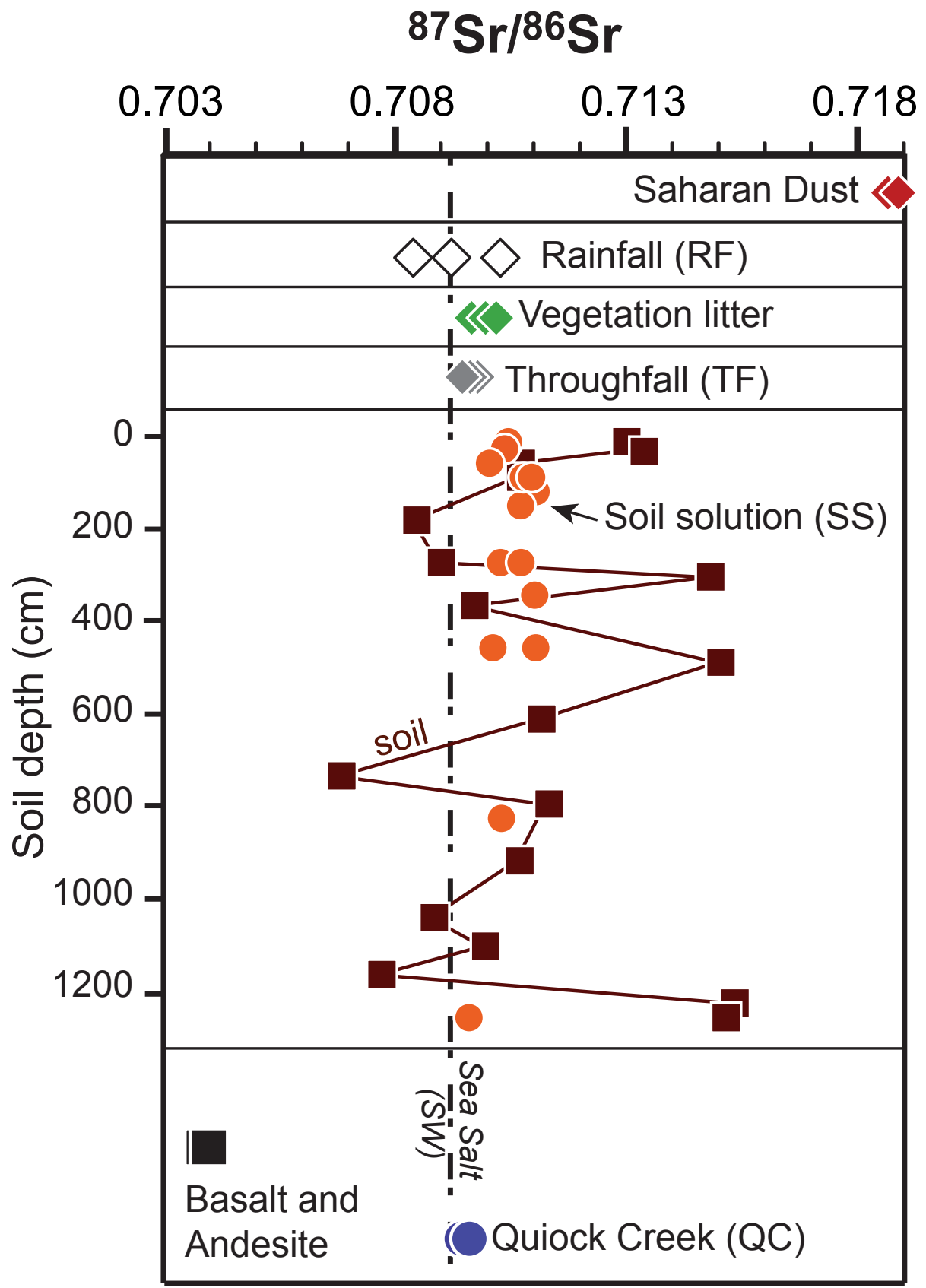


$\mathrm{Ca} / \mathrm{Cl}$
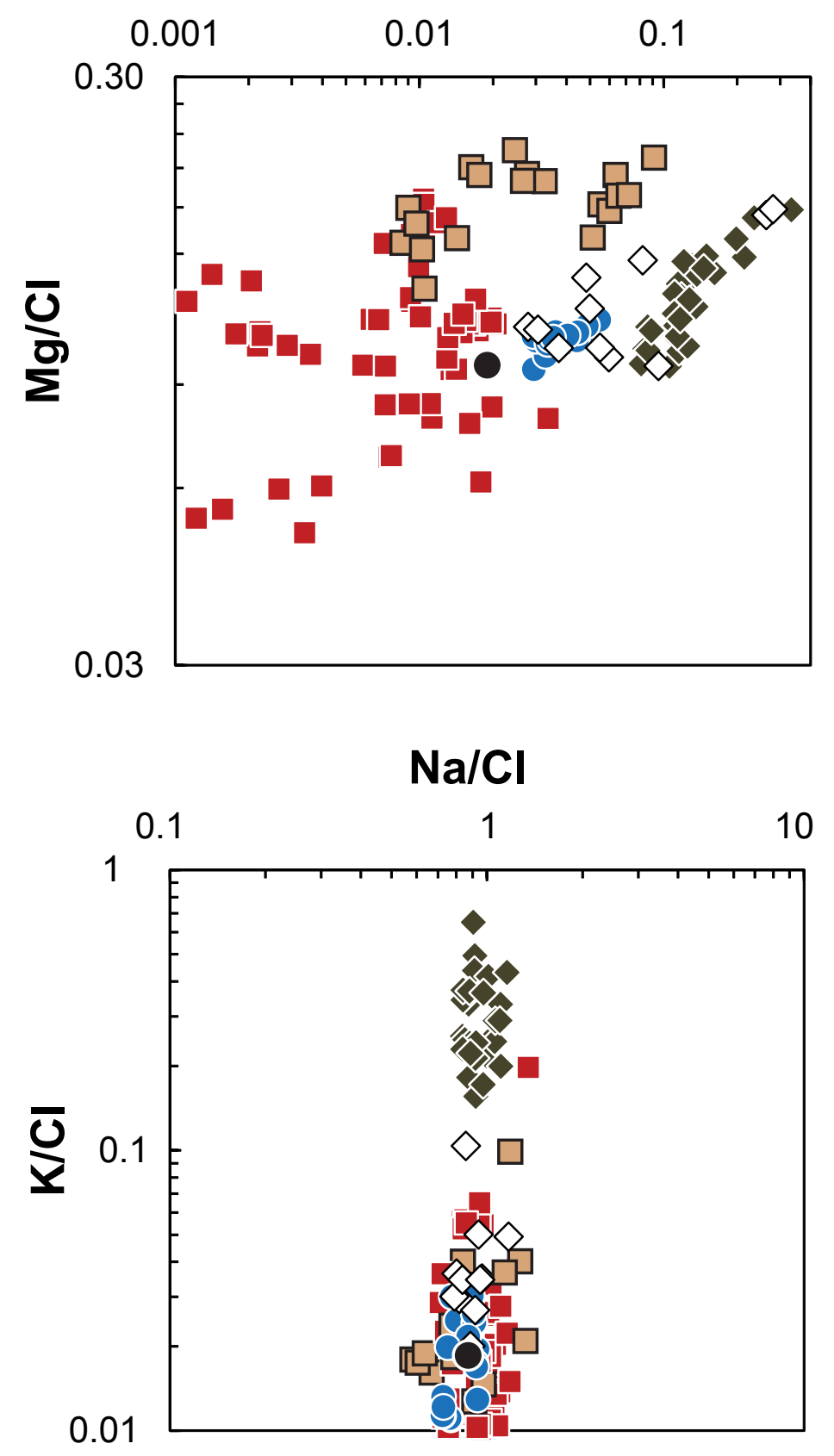

\section{$\mathrm{Ca} / \mathrm{Cl}$}

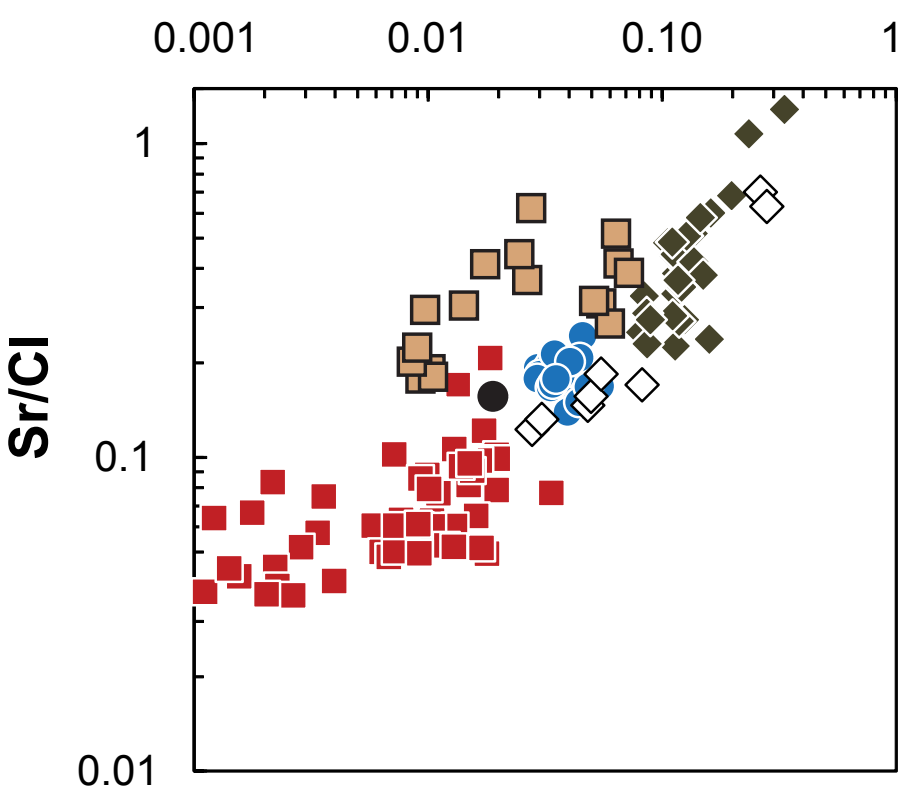

\section{$\mathrm{Ca} / \mathrm{Cl}$}

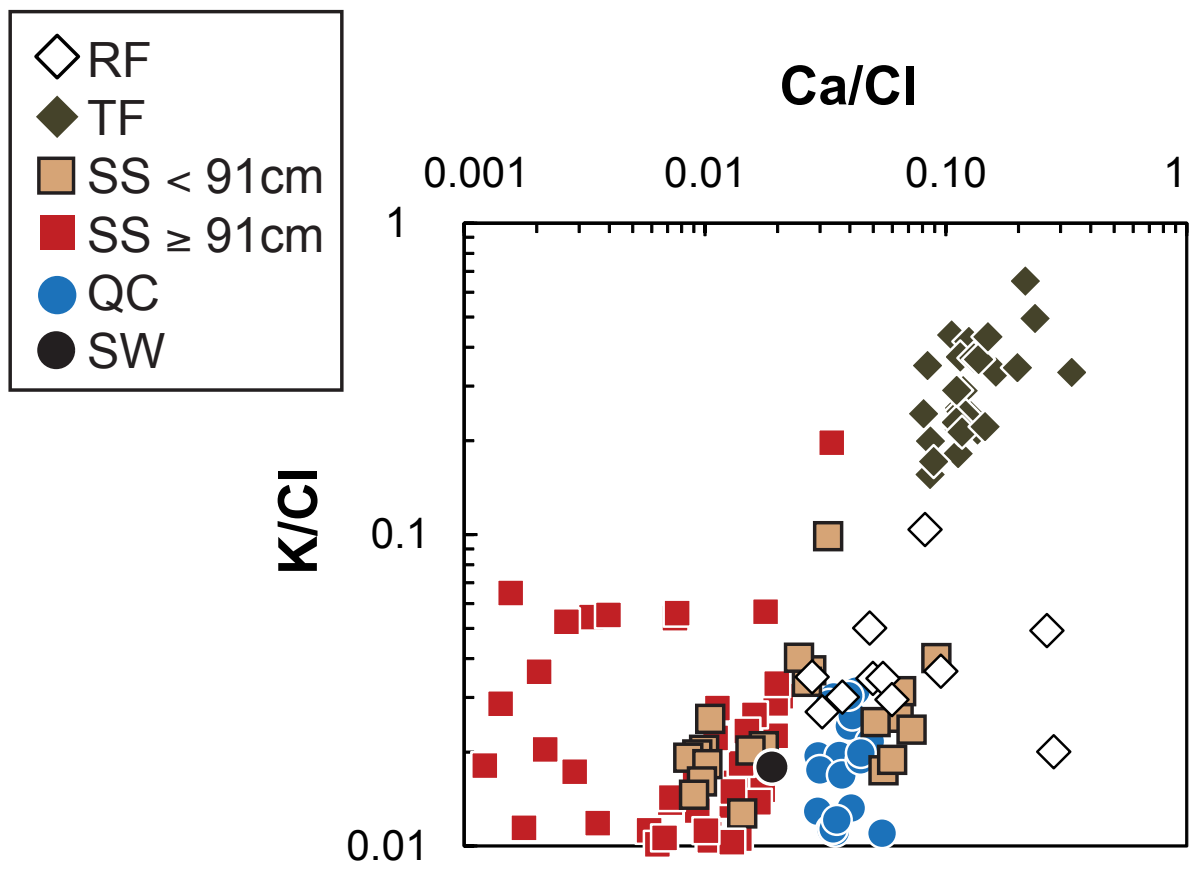




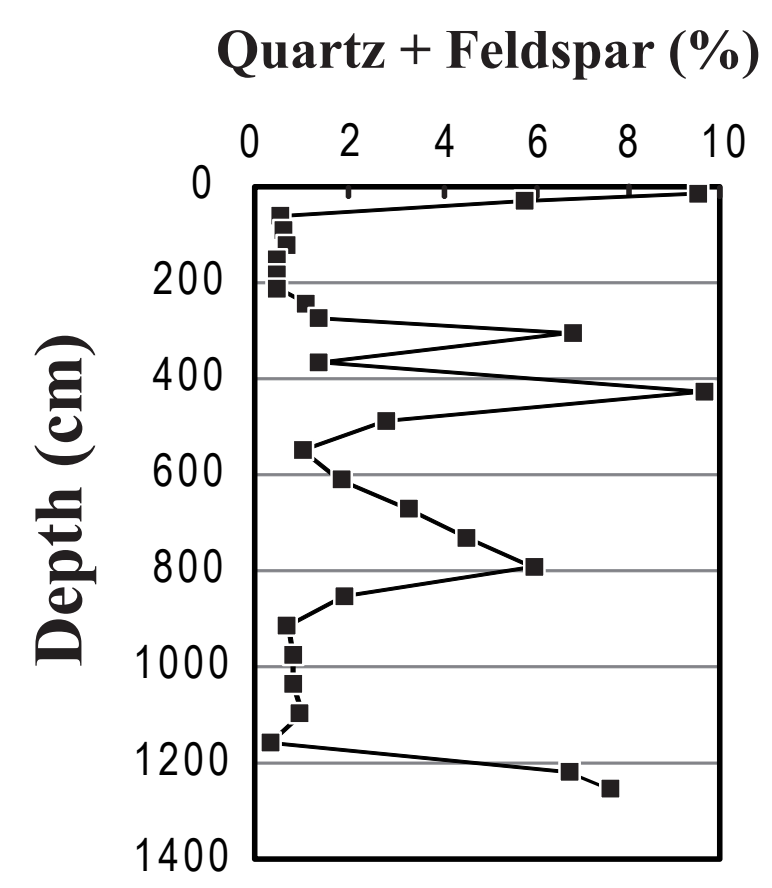

$\tau \mathrm{Sr}$

${ }^{87} \mathbf{S r} / \mathbf{8 6} \mathbf{S r}$

ENd

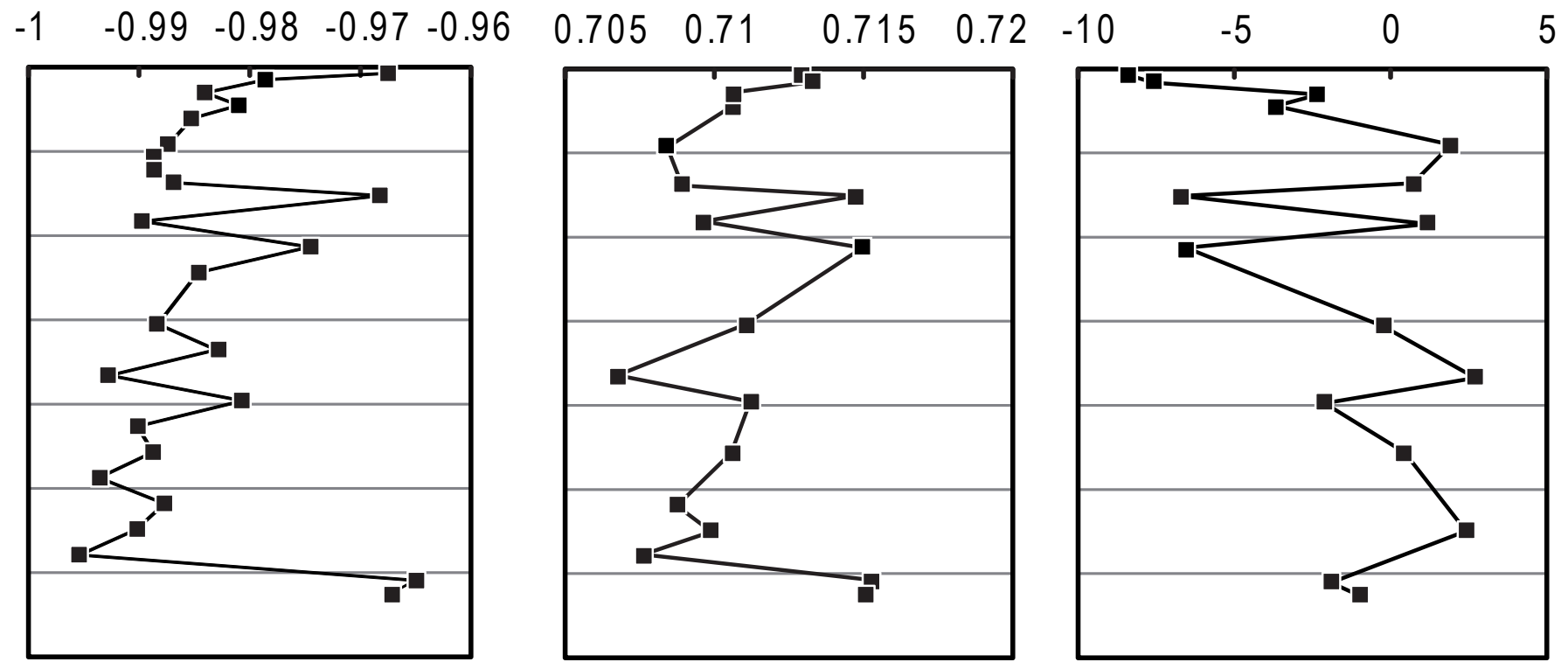




\section{Mg}

$$
\mathrm{F}_{\mathrm{LF}}
$$$$
24 .
$$

(1) $v-13=$

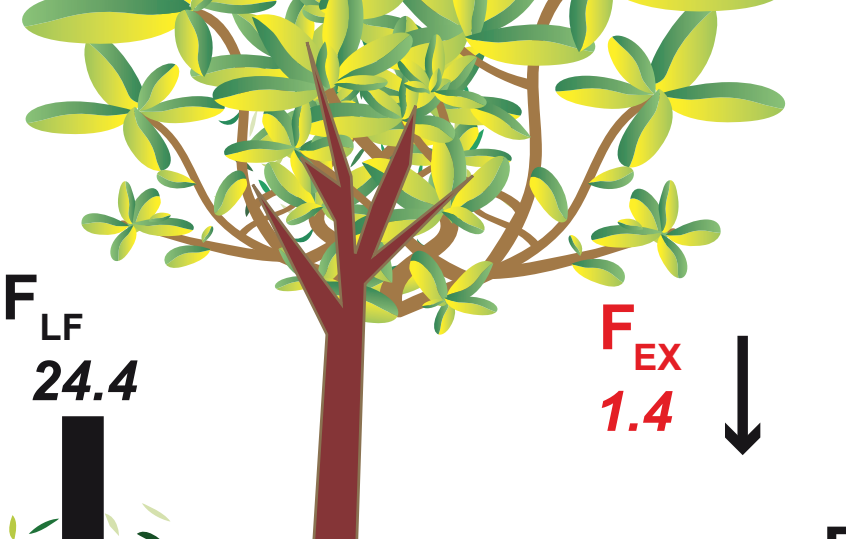

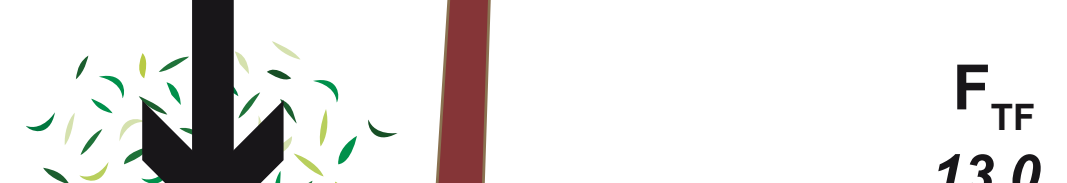

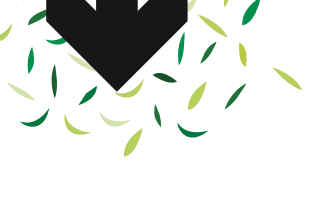

Soil

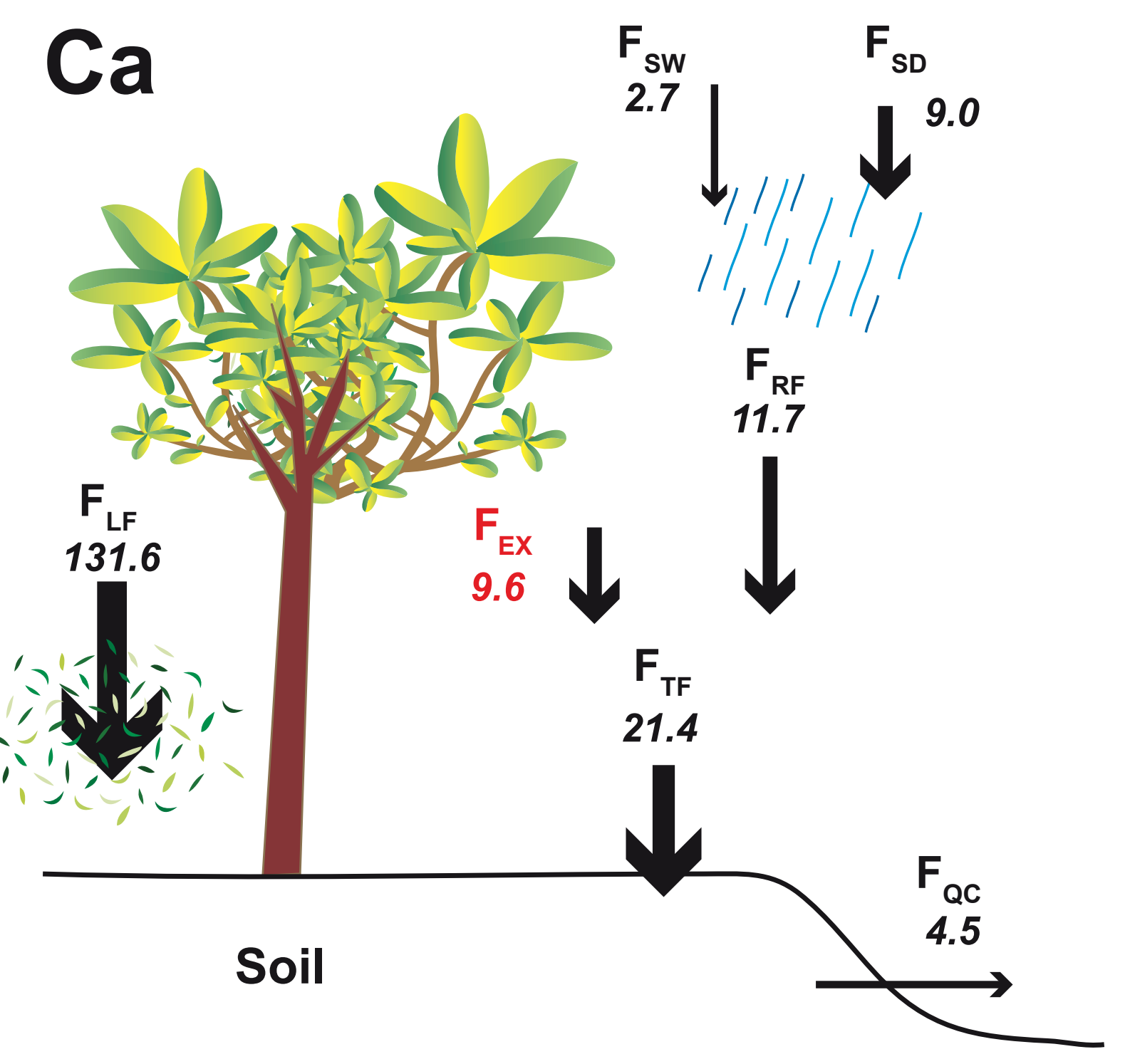

$\mathrm{Na}$

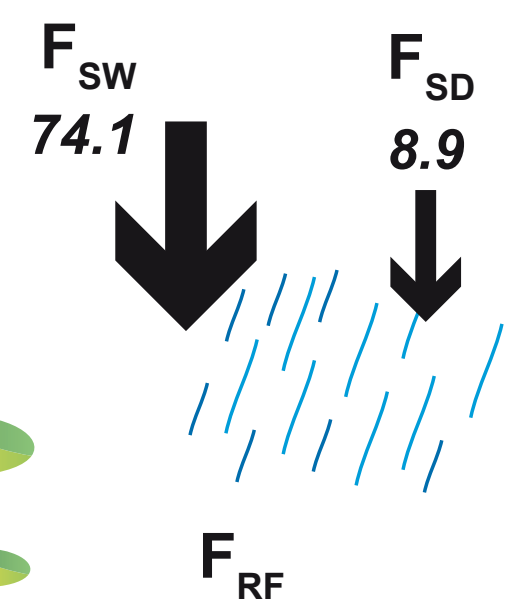

$\mathrm{F}_{\mathrm{RF}}$

11.7

$\mathrm{F}_{\mathrm{QC}}$

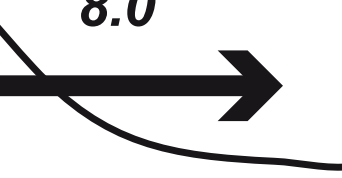

Soil

83.0

$\mathrm{F}_{\mathrm{TF}}$

83.0

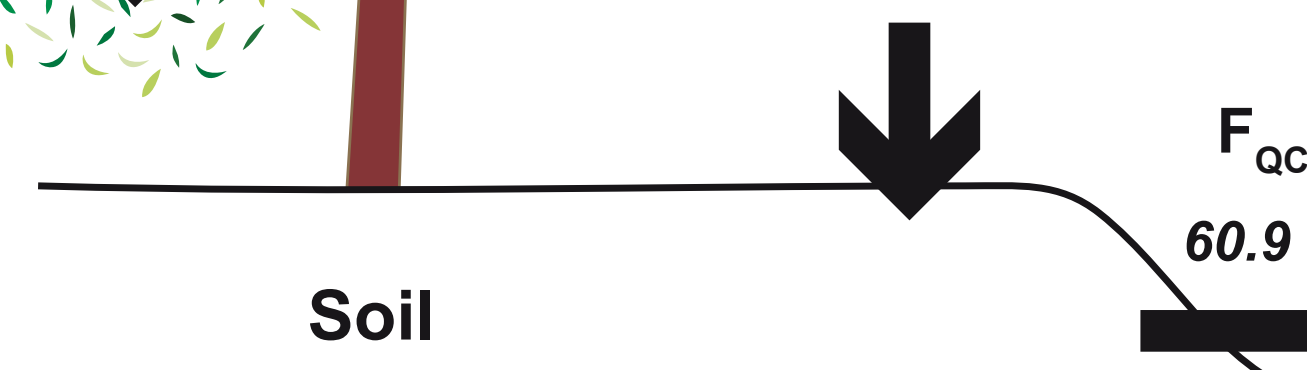

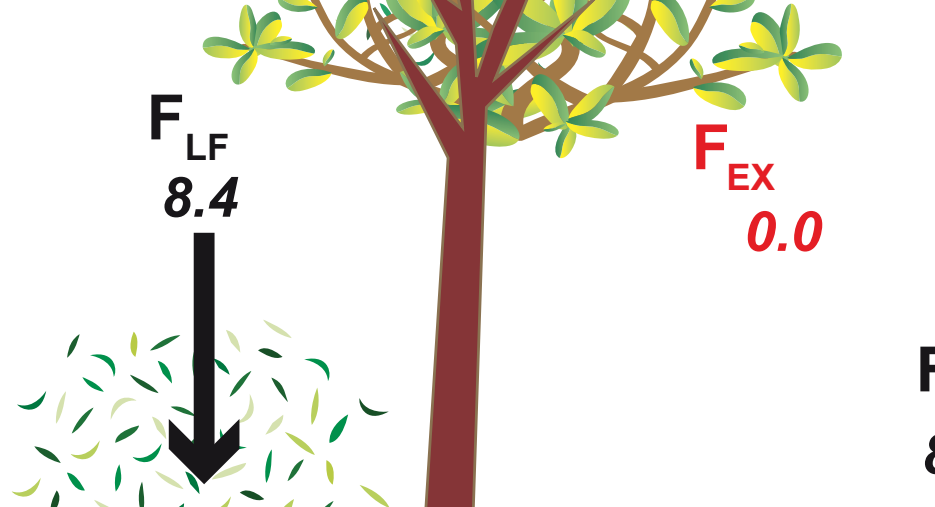
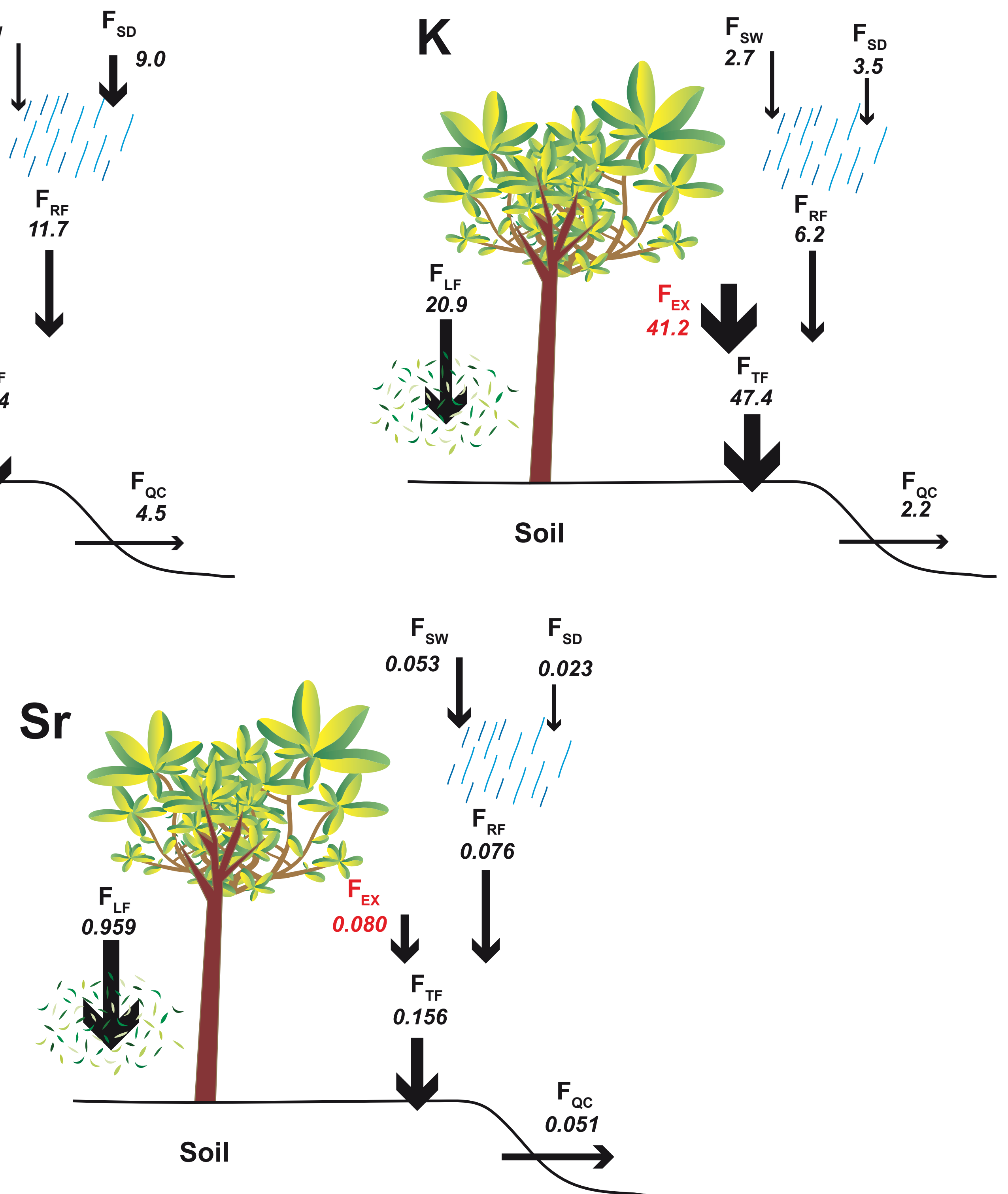


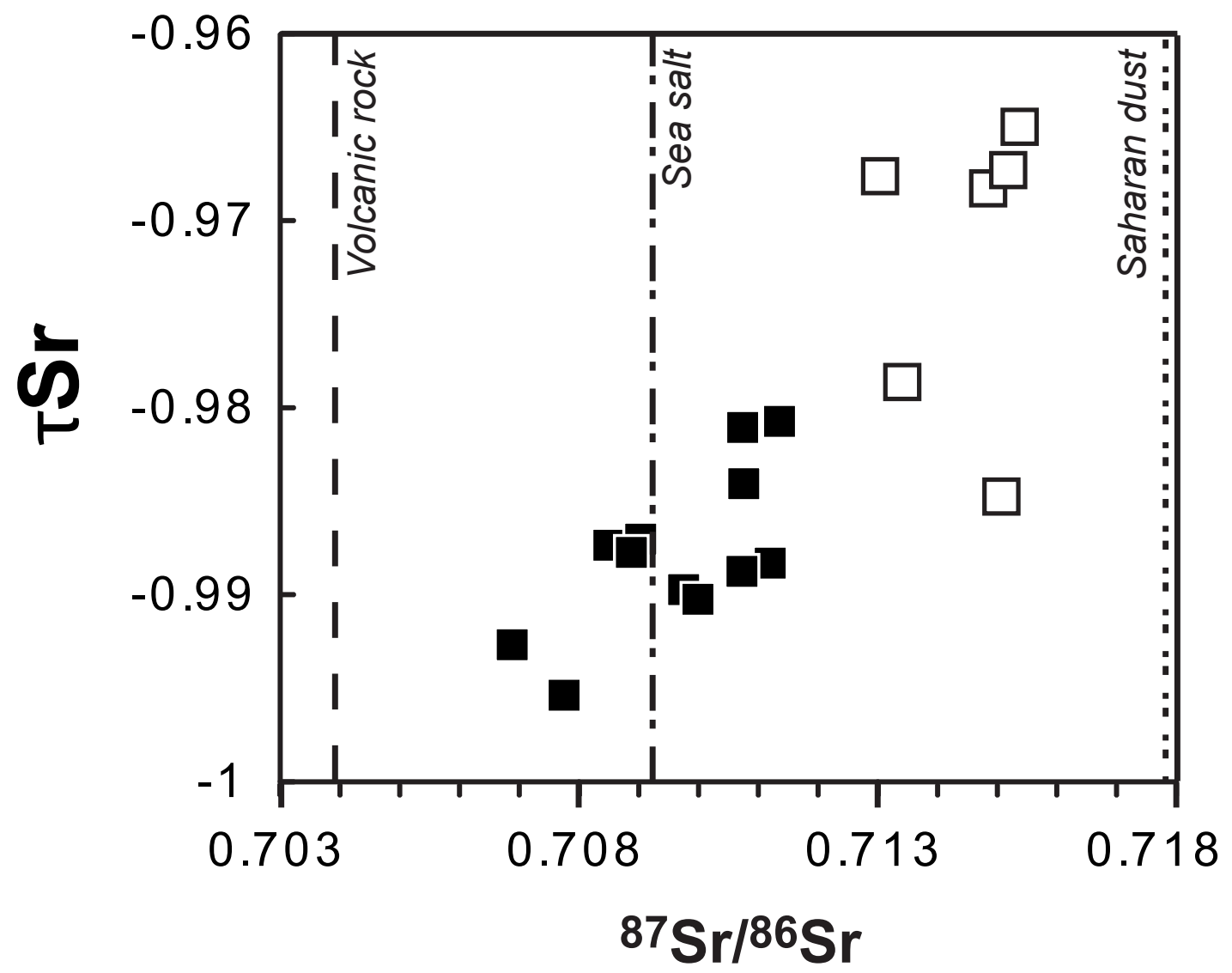




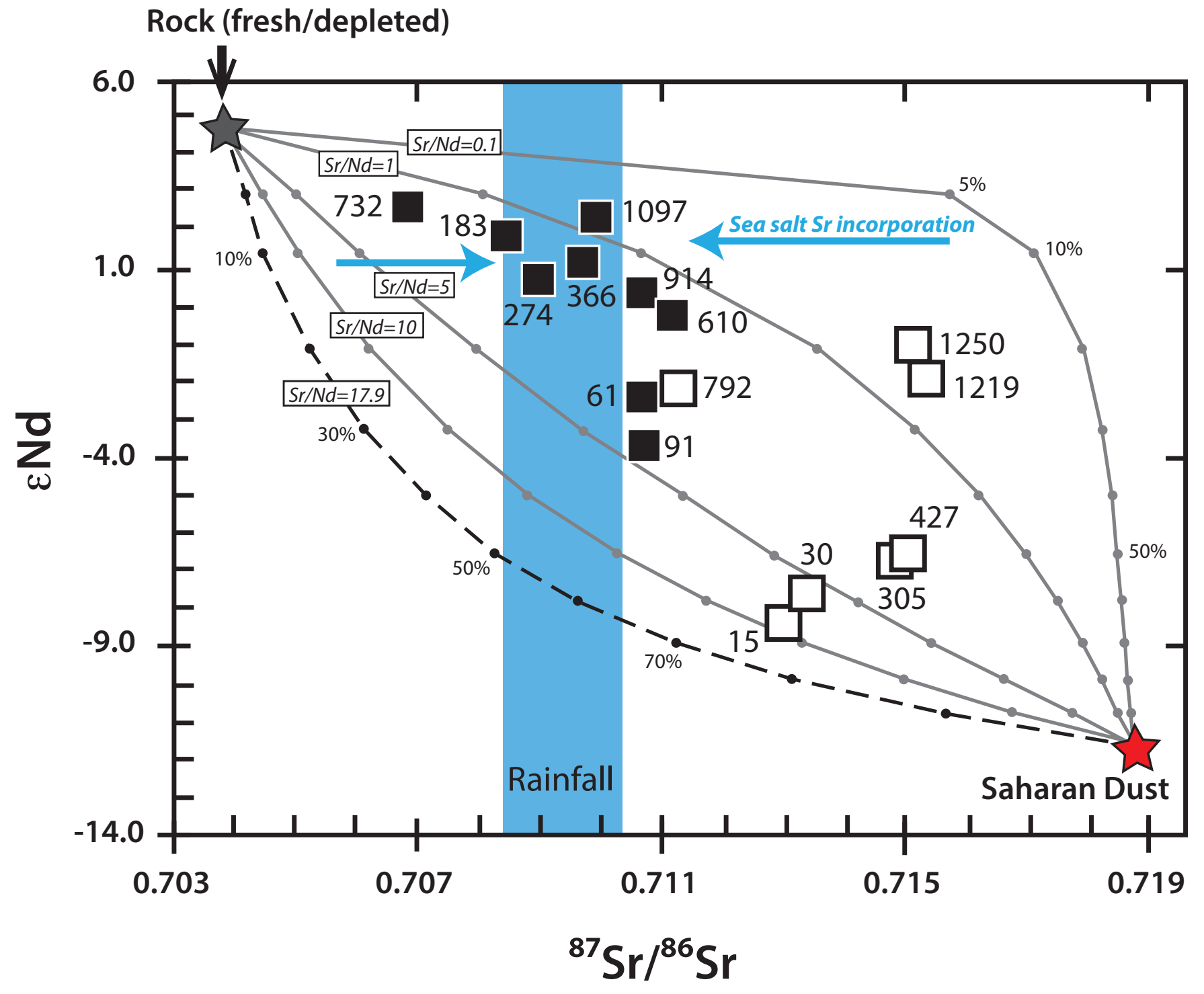


Tables_Results

Table 1: Major element concentrations are from Clergue et al. (2015). Sr concentrations and Sr isotopic signature in water samples are new data.

\begin{tabular}{|c|c|c|c|c|c|c|c|c|c|}
\hline Sample name & $\begin{array}{c}\text { Date } \\
\mathrm{dd} / \mathrm{mm} / \mathrm{yy}\end{array}$ & pH & $\underset{\mu \mathrm{mol} / \mathrm{L}}{\mathbf{N a}}$ & $\underset{\mu \mathrm{mol} / \mathrm{L}}{\mathbf{C l}}$ & $\underset{\mu \mathrm{mol} / \mathrm{L}}{\mathbf{C a}}$ & $\underset{\mu \mathrm{mol} / \mathrm{L}}{\mathbf{M g}}$ & $\underset{\mu \mathrm{mol} / \mathrm{L}}{\mathbf{K}}$ & $\underset{\mu \mathrm{mol} / \mathrm{L}}{\mathbf{S r}}$ & ${ }^{87} \mathrm{Sr} /{ }^{86} \mathrm{Sr}$ \\
\hline \multicolumn{10}{|l|}{ Rainfall (RF) } \\
\hline RF-OVSG & $20 / 03 / 13$ & 4.8 & 82 & 85 & 2 & 10 & 3 & 0.010 & 0.70918 \\
\hline RF-OVSG & $04 / 04 / 13$ & 5.1 & 76 & 88 & 7 & 13 & 9 & 0.015 & 0.70841 \\
\hline RF-OVSG & $15 / 07 / 13$ & $\mathrm{nd}^{\mathrm{a}}$ & 96 & nd & 7 & 14 & 5 & 0.034 & 0.71029 \\
\hline \multicolumn{10}{|l|}{ Throughfall (TF) } \\
\hline TF collector $n^{\circ} 2$ & $21 / 11 / 11$ & nd & 25 & 27 & 6 & 4 & 18 & 0.121 & 0.70965 \\
\hline TF collector $n^{\circ} 1$ & $10 / 08 / 12$ & 6.1 & 81 & 92 & 15 & 13 & 31 & 0.056 & 0.70978 \\
\hline TF collector $n^{\circ} 3$ & $21 / 03 / 13$ & 5.6 & 71 & 64 & 6 & 7 & 13 & 0.015 & 0.70953 \\
\hline TF collector $\mathrm{n}^{\circ} 1$ & $03 / 04 / 13$ & nd & 155 & 168 & 14 & 19 & 26 & 0.048 & 0.70969 \\
\hline TF collector $n^{\circ} 3$ & 03/04/13 & nd & 154 & 158 & 14 & 18 & 27 & 0.043 & 0.70972 \\
\hline TF collector $\mathrm{n}^{\circ} 1$ & $25 / 06 / 13$ & 5.6 & 117 & 132 & 17 & 17 & 32 & 0.067 & 0.70968 \\
\hline \multicolumn{10}{|l|}{ Soil solution $(S S)^{b}$} \\
\hline GBD2_91 & $26 / 10 / 12$ & 5.1 & 226 & 211 & 3 & 21 & 3 & 0.022 & 0.71070 \\
\hline GBD2_122 & $26 / 10 / 12$ & 4.9 & 171 & 145 & 2 & 16 & 2 & 0.009 & 0.71097 \\
\hline GBD2_152 & $26 / 10 / 12$ & 4.6 & 153 & 141 & 1 & 22 & 1 & 0.008 & 0.71063 \\
\hline GBD2_274 & $26 / 10 / 12$ & 4.6 & 209 & 241 & 4 & 28 & 5 & 0.022 & 0.71020 \\
\hline GBD2_344 & $26 / 10 / 12$ & 4.5 & 207 & 244 & 0 & 30 & 2 & 0.009 & 0.71094 \\
\hline GBD2_457 & $26 / 10 / 12$ & 4.5 & 194 & 168 & 2 & 14 & 4 & 0.013 & 0.71004 \\
\hline GBD2_15 & $28 / 06 / 13$ & nd & 118 & 130 & 2 & 21 & 2 & 0.039 & 0.71037 \\
\hline GBD2_30 & $28 / 06 / 13$ & 5.4 & 147 & 150 & 1 & 27 & 2 & 0.034 & 0.71029 \\
\hline GBD2_61 & $28 / 06 / 13$ & 4.8 & 126 & 163 & 12 & 31 & 4 & 0.063 & 0.70996 \\
\hline GBD2_91 & $28 / 06 / 13$ & 5.3 & 194 & 207 & 3 & 25 & 2 & 0.020 & 0.71087 \\
\hline GBD2_274 & $28 / 06 / 13$ & 4.7 & 161 & 221 & 2 & 26 & 2 & 0.017 & 0.71064 \\
\hline GBD2_457 & $28 / 06 / 13$ & 5.4 & 159 & 167 & 2 & 14 & 3 & 0.010 & 0.71097 \\
\hline GBD2_823 & $28 / 06 / 13$ & nd & 210 & 243 & 1 & 15 & 13 & 0.010 & 0.71022 \\
\hline \multicolumn{10}{|l|}{ Quiock Creek } \\
\hline QC & $23 / 04 / 12$ & nd & 184 & 229 & 11 & 25 & 6 & 0.056 & 0.70939 \\
\hline QC & 03/08/12 & nd & 248 & 271 & 9 & 29 & 5 & 0.052 & 0.70922 \\
\hline QC & $26 / 10 / 12$ & 4.7 & 254 & 271 & 8 & 30 & 4 & 0.048 & 0.70933 \\
\hline QC & $21 / 03 / 13$ & 4.8 & 211 & 274 & 15 & 32 & 3 & 0.046 & 0.70928 \\
\hline
\end{tabular}

${ }^{\mathrm{a}}$ nd=not determined.

${ }^{\mathrm{b}}$ For soil solution sample names GBD2_X, X=depth in $\mathrm{cm}$. 
Table 2: Range of concentration in the different compartments (mean value/median value) from Clergue et al. (2015).

\begin{tabular}{lccccc}
\hline & $\mathrm{K}(\mu \mathrm{mol} / \mathrm{L})$ & $\mathrm{Na}(\mu \mathrm{mol} / \mathrm{L})$ & $\mathrm{Mg}(\mu \mathrm{mol} / \mathrm{L})$ & $\mathrm{Ca}(\mu \mathrm{mol} / \mathrm{L})$ & $\mathrm{Cl}(\mu \mathrm{mol} / \mathrm{L})$ \\
\hline $\mathrm{RF}^{*}(\mathrm{n}=13)$ & $1-9(4 / 3)$ & $41-165(89 / 79)$ & $1-22(12 / 11)$ & $1-15(7 / 7)$ & $49-167(92 / 85)$ \\
$\mathrm{TF}(\mathrm{n}=48)$ & $10-108(39 / 32)$ & $17-264(117 / 102)$ & $3-40(17 / 17)$ & $3-36(17 / 16)$ & $23-264(125 / 99)$ \\
$\mathrm{SS}(\mathrm{n}=75)$ & $1-39(5 / 3)$ & $112-266(179 / 182)$ & $11-58(24 / 25)$ & $0.3-14(3 / 2)$ & $85-345(199 / 203)$ \\
$\mathrm{QC}(\mathrm{n}=57)$ & $3-12(5 / 5)$ & $184-282(234 / 239)$ & $24-35(29 / 29)$ & $7-15(10 / 10)$ & $229-315(272 / 274)$ \\
\hline
\end{tabular}

*: MF + OVSG rainfall. 
Table 3: Chemical and isotopic ( $\mathrm{Sr}$ and $\mathrm{Nd}$ ) composition of soil, rock, Saharan dust and vegetation samples. Some $\mathrm{Nd}$ isotopic composition of soils (highlighted) and $\mathrm{Ca}, \mathrm{K}, \mathrm{Mg}, \mathrm{Na}$, Ti concentrations are from Clergue et al. (2015).

\begin{tabular}{|c|c|c|c|c|c|c|c|c|}
\hline Sample name & $\begin{array}{c}\mathbf{C a} \\
\mathrm{ppm}\end{array}$ & $\begin{array}{c}\mathbf{K} \\
\text { ppm }\end{array}$ & $\begin{array}{c}\mathbf{M g} \\
\text { ppm }\end{array}$ & $\begin{array}{c}\mathbf{N a} \\
\text { ppm }\end{array}$ & $\begin{array}{c}\mathbf{T i} \\
\mathrm{ppm}\end{array}$ & $\begin{array}{c}\mathbf{S r} \\
\mathrm{ppm}\end{array}$ & ${ }^{87} \mathrm{Sr} /{ }^{86} \mathrm{Sr}$ & ENd \\
\hline \multicolumn{9}{|l|}{ Saharan Dust } \\
\hline Saharan 1 & 1747 & 5474 & 5355 & 951 & nd & 52 & 0.71865 & nd \\
\hline Saharan 2 & 1918 & 5134 & 5059 & 930 & nd & 49 & 0.71882 & nd \\
\hline \multicolumn{9}{|c|}{ Vegetation Litter } \\
\hline Leaves 1 & 30533 & 5987 & 5441 & 1356 & nd & 203 & 0.71019 & nd \\
\hline Leaves 2 & 10237 & 2302 & 1960 & 1857 & nd & 80 & 0.71010 & nd \\
\hline Branches 1 & 14234 & 1315 & 2730 & 581 & nd & 112 & 0.70966 & nd \\
\hline Branches 2 & 12468 & 1122 & 2397 & 504 & nd & 98 & 0.70975 & nd \\
\hline Roots & 16410 & 11390 & 5676 & 2459 & nd & 94 & 0.70976 & nd \\
\hline \multicolumn{9}{|l|}{ Soil ${ }^{a}$} \\
\hline GBD2_15 & 306 & 1087 & 1977 & 681 & 8573 & 13 & 0.71293 & $\underline{-8.39}$ \\
\hline GBD2_30 & 147 & 643 & 1339 & 404 & 8873 & 9 & 0.71331 & -7.57 \\
\hline GBD2_61 & 45 & 356 & 1189 & 356 & 7913 & 6 & 0.71065 & $\underline{-2.35}$ \\
\hline GBD2_91 & 43 & 455 & 1207 & 295 & 6894 & 6 & 0.71064 & -3.66 \\
\hline GBD2_183 & 41 & 174 & 1287 & 444 & 7674 & 4 & 0.70840 & $\underline{1.92}$ \\
\hline GBD2_274 & 28 & 249 & 1043 & 248 & 7374 & 4 & 0.70893 & 0.74 \\
\hline GBD2_305 & 47 & 1026 & 1499 & 353 & 8033 & 12 & 0.71474 & $\underline{-6.70}$ \\
\hline GBD2_366 & 35 & 194 & 1068 & 344 & 8153 & 4 & 0.70964 & 1.19 \\
\hline GBD2_427 & 28 & 615 & 1262 & 158 & 10132 & 7 & 0.71496 & -6.54 \\
\hline GBD2_610 & 34 & 326 & 1419 & 264 & 7314 & 4 & 0.71109 & -0.21 \\
\hline GBD2_732 & 36 & 317 & 825 & 160 & 6834 & 2 & 0.70677 & 2.71 \\
\hline GBD2_792 & 43 & 621 & 880 & 278 & 5096 & 4 & 0.71125 & -2.12 \\
\hline GBD2_914 & 29 & 321 & 1196 & 339 & 7074 & 4 & 0.71062 & 0.42 \\
\hline GBD2_1036 & 48 & 258 & 1234 & 347 & 6714 & 4 & 0.70877 & nd \\
\hline GBD2_1097 & 23 & 242 & 946 & 291 & 5995 & 3 & 0.70988 & $\underline{2.44}$ \\
\hline GBD2_1158 & 41 & 215 & 1341 & 324 & 9052 & 2 & 0.70764 & nd \\
\hline GBD2_1219 & 78 & 1276 & 1612 & 277 & 7674 & 12 & 0.71527 & -1.89 \\
\hline GBD2_1250 & 60 & 971 & 1312 & 215 & 8273 & 12 & 0.71508 & -0.97 \\
\hline \multicolumn{9}{|l|}{ Volcanic Rock ${ }^{b}$} \\
\hline 04GW12 & 48462 & 7308 & 9060 & 27328 & 5373 & 244 & 0.70388 & 5.45 \\
\hline 00GU44 & 74521 & 5175 & 29483 & 20282 & 5466 & 331 & 0.70380 & 4.34 \\
\hline 03GU75 & 68417 & 4325 & 26106 & 21669 & 5796 & 283 & 0.70385 & 4.67 \\
\hline
\end{tabular}

a for soil sample names GBD2_X, X=depth in cm

${ }^{\mathrm{b}}$ rock samples from Samper et al. (2007). 
Table 4: Elemental annual flux $\left(\mathrm{kg} \cdot \mathrm{ha}^{-1} \cdot \mathrm{yr}^{-1}\right)$, stock $\left(\mathrm{kg} \cdot \mathrm{ha}^{-1}\right)$ and residence time (yr) in the Quiock Creek catchment.

\begin{tabular}{|c|c|c|c|c|c|}
\hline & $\mathbf{N a}$ & $\mathbf{C a}$ & Mg & $\mathbf{K}$ & $\mathrm{Sr}$ \\
\hline Rainfall flux (FRF) & 83.0 & 11.7 & 11.7 & 6.2 & 0.076 \\
\hline Sea Salt flux (FSW) & 74.1 & 2.7 & 9.6 & 2.7 & 0.053 \\
\hline Saharan dust leaching flux (FSD) & 8.9 & 9.0 & 2.1 & 3.5 & 0.023 \\
\hline Throughfall flux (FTF) & 83.0 & 21.4 & 13.0 & 47.4 & 0.156 \\
\hline Sea Salt flux (FSW) & 74.1 & 2.7 & 9.6 & 2.7 & 0.053 \\
\hline Saharan dust leaching flux (FSD) & 8.9 & 9.0 & 2.1 & 3.5 & 0.023 \\
\hline Leaf excretion flux (FEX) & 0.0 & 9.6 & 1.4 & 41.2 & 0.080 \\
\hline Vegetation flux (FVEG) & 8.4 & 141.5 & 25.8 & 62.1 & 1.039 \\
\hline Litter fall flux $(F L F)$ & 8.4 & 131.9 & 24.4 & 20.9 & 0.959 \\
\hline Leaf excretion flux (FEX) & 0.0 & 9.6 & 1.4 & 41.2 & 0.080 \\
\hline Vegetation Stock & 405.1 & 6355.9 & 1180.1 & 1010.6 & 46.3 \\
\hline Residence time (Tres) & 48.2 & 44.9 & 45.7 & 16.0 & 44.6 \\
\hline Quiock Creek flux (FQC) & 60.9 & 4.5 & 8.0 & 2.2 & 0.051 \\
\hline
\end{tabular}

Calculations are described by equations 2 to 9 . 
Table 1S: ICP AES (for major elements) and ICP MS (for Sr) analyses of rock and vegetation standard reference materials.

\begin{tabular}{|c|c|c|c|c|c|c|c|}
\hline & $\mathrm{Al}$ & $\mathrm{Ca}$ & $\mathrm{Fe}$ & $\mathrm{K}$ & $\mathrm{Mg}$ & $\mathrm{Na}$ & $\mathrm{Sr}$ \\
\hline & ppm & ppm & ppm & ppm & ppm & ppm & ppm \\
\hline \multicolumn{8}{|l|}{ Rock standards } \\
\hline BEN certif ${ }^{1}$ & 53312 & 99071 & 89880 & 11534 & 79291 & 23594 & 1370 \\
\hline \multirow[t]{2}{*}{ BEN (this study) } & 54289 & 99897 & 90935 & 11739 & 79269 & 23846 & 1655 \\
\hline & 52140 & 95138 & 89888 & 11397 & 76588 & 23325 & \\
\hline GSN certif ${ }^{1}$ & 77665 & 17857 & 26250 & 38419 & 13868 & 27971 & 570 \\
\hline \multirow[t]{3}{*}{ GSN (this study) } & 77987 & 17562 & 25798 & 35813 & 13629 & 26838 & 531 \\
\hline & 77673 & 17467 & 25594 & 35454 & 13600 & 26723 & 554 \\
\hline & 80519 & 17834 & 26123 & 37214 & 13770 & 27587 & \\
\hline \multicolumn{8}{|l|}{ Vegetation standard } \\
\hline NIST_SRM 1515 (certif) & 286 & 15260 & 83 & 16000 & 2700 & 24.4 & 25 \\
\hline \multirow[t]{4}{*}{ NIST_SRM 1515 (this study) } & 283 & 14441 & 69 & 15216 & 2421 & 55 & \\
\hline & 290 & 14349 & 73 & 15544 & 2478 & 57 & \\
\hline & 283 & 14872 & 75 & 16102 & 2662 & 42 & \\
\hline & 286 & 15014 & 76 & 16307 & 2682 & 42 & \\
\hline
\end{tabular}

${ }^{1}$ Recommended values of GSN, BEN are taken from CRPG certificate of analyze (http://helium.crpg.cnrsnancy.fr/SARM/pages/geostandards.html\#). 
Table 2S : Sr concentration in throughfall, rainfall and Quiock Creek samples

\begin{tabular}{|c|c|c|c|c|c|c|c|c|}
\hline $\begin{array}{c}\text { Sample } \\
\text { name }\end{array}$ & Date & $\begin{array}{c}\mathrm{Sr} \\
\mu \mathrm{mol} / /\end{array}$ & Sample name & Date & $\begin{array}{c}\mathrm{Sr} \\
\mu \mathrm{mol} / \mathrm{I}\end{array}$ & $\begin{array}{c}\text { Sample } \\
\text { name }\end{array}$ & Date & $\begin{array}{c}\mathrm{Sr} \\
\mu \mathrm{mol} / \mathrm{I}\end{array}$ \\
\hline \multicolumn{9}{|l|}{ Throughfall } \\
\hline TF col nº 1 & $14 / 11 / 2011$ & 0.136 & TF col n³ & $25 / 03 / 2013$ & 0.041 & QC & $16 / 03 / 2012$ & 0.064 \\
\hline TF col n² & $14 / 11 / 2011$ & 0.129 & TF col nº 1 & $27 / 03 / 2013$ & 0.070 & QC & 04/04/2012 & 0.057 \\
\hline TF col n 1 & $21 / 11 / 2011$ & 0.025 & TF col n³ & $27 / 03 / 2013$ & 0.049 & QC & 09/04/2012 & 0.058 \\
\hline TF col n² & $21 / 11 / 2011$ & 0.121 & TF col n¹ & 29/03/2013 & 0.070 & QC & $13 / 04 / 2012$ & 0.058 \\
\hline TF col n³ & $21 / 11 / 2011$ & 0.038 & TF col n³ & 29/03/2013 & 0.050 & QC & $19 / 04 / 2012$ & 0.070 \\
\hline TF col n 1 & $25 / 11 / 2011$ & 0.035 & TF col n 1 & $01 / 04 / 2013$ & 0.018 & QC & $23 / 04 / 2012$ & 0.056 \\
\hline TF col n² & $25 / 11 / 2011$ & 0.026 & TF col n³ & $01 / 04 / 2013$ & 0.016 & $\mathrm{QC}$ & 26/04/2012 & 0.056 \\
\hline TF col n³ & $25 / 11 / 2011$ & 0.035 & TF col n 1 & $03 / 04 / 2013$ & 0.048 & QC & 08/06/2012 & 0.054 \\
\hline TF col n 1 & 09/04/2012 & 0.012 & TF col n³ & 03/04/2013 & 0.043 & QC & 03/08/2012 & 0.052 \\
\hline TF col n² & 09/04/2012 & 0.067 & TF col n 1 & $25 / 06 / 2013$ & 0.067 & $\mathrm{QC}$ & 05/08/2012 & 0.053 \\
\hline TF col n³ & 09/04/2012 & 0.037 & TF col n³ & $25 / 06 / 2013$ & 0.062 & QC & $10 / 08 / 2012$ & 0.053 \\
\hline TF col n ${ }^{\circ} 1$ & $13 / 04 / 2012$ & 0.126 & TF col n 1 & $26 / 06 / 2013$ & 0.048 & QC & $16 / 08 / 2012$ & 0.050 \\
\hline TF col n² & $13 / 04 / 2012$ & 0.076 & TF col n³ & $26 / 06 / 2013$ & 0.036 & QC & 07/09/2012 & 0.050 \\
\hline TF col n³ & $13 / 04 / 2012$ & 0.049 & TF col n 1 & $28 / 06 / 2013$ & 0.043 & QC & 05/10/2012 & 0.050 \\
\hline TF col n² & $16 / 04 / 2012$ & 0.027 & & & & QC & 23/10/2012 & 0.049 \\
\hline TF col n³ & $16 / 04 / 2012$ & 0.023 & Rainfall & & & QC & $26 / 10 / 2012$ & 0.048 \\
\hline TF col n 1 & $19 / 04 / 2012$ & 0.119 & RF-MF & 03/08/2012 & 0.039 & QC & $30 / 11 / 2012$ & 0.037 \\
\hline TF col n² & $19 / 04 / 2012$ & 0.113 & RF-MF & $10 / 08 / 2012$ & 0.034 & QC & $14 / 12 / 2012$ & 0.035 \\
\hline TF col n³ & $19 / 04 / 2012$ & 0.109 & RF-OVSG & 20/03/2013 & 0.010 & QC & $18 / 01 / 2013$ & 0.037 \\
\hline TF col n 1 & $23 / 04 / 2012$ & 0.011 & RF-OVSG & $21 / 03 / 2013$ & 0.011 & QC & $01 / 02 / 2013$ & 0.037 \\
\hline TF col n² & $23 / 04 / 2012$ & 0.010 & RF-OVSG & $27 / 03 / 2013$ & 0.021 & $\mathrm{QC}$ & 01/03/2013 & 0.046 \\
\hline TF col n³ & $23 / 04 / 2012$ & 0.008 & RF-OVSG & $31 / 03 / 2013$ & 0.009 & QC & 20/03/2013 & 0.045 \\
\hline TF col n 1 & 05/08/2012 & 0.031 & RF-OVSG & $01 / 04 / 2013$ & 0.017 & $\mathrm{QC}$ & $21 / 03 / 2013$ & 0.046 \\
\hline TF col n² & 05/08/2012 & 0.032 & RF-OVSG & 04/04/2013 & 0.015 & $\mathrm{QC}$ & $25 / 03 / 2013$ & 0.042 \\
\hline TF col n³ & 05/08/2012 & 0.038 & RF-OVSG & $15 / 07 / 2013$ & 0.034 & $\mathrm{QC}$ & 29/03/2013 & 0.039 \\
\hline TF col n 1 & $10 / 08 / 2012$ & 0.056 & & & & $\mathrm{QC}$ & $01 / 04 / 2013$ & 0.039 \\
\hline TF col n² & $10 / 08 / 2012$ & 0.060 & Quiock Creek & & & QC & 03/04/2013 & 0.042 \\
\hline TF col n³ & $10 / 08 / 2012$ & 0.121 & $\mathrm{QC}$ & $14 / 10 / 2011$ & 0.059 & $\mathrm{QC}$ & 24/05/2013 & 0.056 \\
\hline TF col n ${ }^{\circ} 1$ & $16 / 08 / 2012$ & 0.098 & $\mathrm{QC}$ & $10 / 11 / 2011$ & 0.069 & $\mathrm{QC}$ & $21 / 06 / 2013$ & 0.048 \\
\hline TF col n² & $16 / 08 / 2012$ & 0.115 & QC & $23 / 11 / 2011$ & 0.068 & QC & $25 / 06 / 2013$ & 0.051 \\
\hline TF col n³ & $16 / 08 / 2012$ & 0.136 & QC & 09/12/2011 & 0.060 & $\mathrm{QC}$ & 26/06/2013 & 0.052 \\
\hline TF col n 1 & $21 / 03 / 2013$ & 0.017 & $\mathrm{QC}$ & 06/01/2012 & 0.064 & $\mathrm{QC}$ & 28/06/2013 & 0.047 \\
\hline TF col n³ & $21 / 03 / 2013$ & 0.015 & $\mathrm{QC}$ & $03 / 02 / 2012$ & 0.061 & $\mathrm{QC}$ & 02/07/2013 & 0.049 \\
\hline TF col n ${ }^{\circ} 1$ & $25 / 03 / 2013$ & 0.084 & & & & & & \\
\hline
\end{tabular}

